\title{
The Fire INventory from NCAR (FINN): a high resolution global model to estimate the emissions from open burning
}

\author{
C. Wiedinmyer ${ }^{1}$, S. K. Akagi ${ }^{2}$, R. J. Yokelson ${ }^{2}$, L. K. Emmons ${ }^{1}$, J. A. Al-Saadi ${ }^{3}$, J. J. Orlando ${ }^{1}$, and A. J. Soja ${ }^{4}$ \\ ${ }^{1}$ National Center for Atmospheric Research, Boulder, CO, USA \\ ${ }^{2}$ University of Montana, Department of Chemistry, Missoula, MT, USA \\ ${ }^{3}$ NASA Headquarters, Washington DC, USA \\ ${ }^{4}$ National Institute of Aerospace, NASA Langley Research Center, Hampton, VA, USA
}

Received: 3 December 2010 - Published in Geosci. Model Dev. Discuss.: 23 December 2010

Revised: 28 June 2011 - Accepted: 5 July 2011 - Published: 20 July 2011

\begin{abstract}
The Fire INventory from NCAR version 1.0 (FINNv1) provides daily, $1 \mathrm{~km}$ resolution, global estimates of the trace gas and particle emissions from open burning of biomass, which includes wildfire, agricultural fires, and prescribed burning and does not include biofuel use and trash burning. Emission factors used in the calculations have been updated with recent data, particularly for the non-methane organic compounds (NMOC). The resulting global annual NMOC emission estimates are as much as a factor of 5 greater than some prior estimates. Chemical speciation profiles, necessary to allocate the total NMOC emission estimates to lumped species for use by chemical transport models, are provided for three widely used chemical mechanisms: SAPRC99, GEOS-CHEM, and MOZART-4. Using these profiles, FINNv1 also provides global estimates of key organic compounds, including formaldehyde and methanol. Uncertainties in the emissions estimates arise from several of the method steps. The use of fire hot spots, assumed area burned, land cover maps, biomass consumption estimates, and emission factors all introduce error into the model estimates. The uncertainty in the FINNv1 emission estimates are about a factor of two; but, the global estimates agree reasonably well with other global inventories of biomass burning emissions for $\mathrm{CO}, \mathrm{CO}_{2}$, and other species with less variable emission factors. FINNv1 emission estimates have been developed specifically for modeling atmospheric chemistry and air quality in a consistent framework at scales from local to global. The product is unique because of the high temporal
\end{abstract}

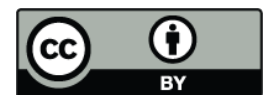

Correspondence to: C. Wiedinmyer (christin@ucar.edu) and spatial resolution, global coverage, and the number of species estimated. FINNv1 can be used for both hindcast and forecast or near-real time model applications and the results are being critically evaluated with models and observations whenever possible.

\section{Introduction}

Open biomass burning, which for this study includes wildfires, agricultural burning, and managed burns and not biofuel use or trash burning, makes up an important part of the total global emissions of both trace gases and particulate matter. According to the EDGARv3.2FT2000 global emissions inventory for 2000 (Olivier et al., 2005; http://edgar.jrc.ec. europa.eu/index.php), open biomass burning produced $51 \%$ of the global carbon monoxide (CO) emissions for 2000 and $20 \%$ of the oxides of nitrogen $\left(\mathrm{NO}_{\mathrm{x}}\right)$ emissions. Current emission inventories estimate that open biomass burning (not including waste burning) emits $26-73 \%$ of global emissions of primary fine organic particulate matter (PM) and 33-41\% of global fine black carbon (BC) PM emissions (Bond et al., 2004; Andreae and Rosenfeld, 2008).

Although episodic in nature and highly variable, open biomass burning emissions can contribute to local, regional, and global air quality problems and climate forcings (Crutzen and Andreae, 1990). The emissions of PM can degrade visibility (e.g., McKeeking et al., 2006) and cause health problems (e.g., Pope and Dockery, 2006). Gas-phase components in fire plumes, including non-methane organic compounds (NMOC) and $\mathrm{NO}_{\mathrm{x}}$, can react downwind of the fire location and contribute to the chemistry that forms ozone (e.g., Pfister

Published by Copernicus Publications on behalf of the European Geosciences Union. 
et al., 2008). Carbon dioxide released to the atmosphere from large scale burning may have important implications for the carbon cycle (e.g., IPCC 2007; Wiedinmyer and Neff, 2007). Due to the importance of these emissions, reasonable estimates of open burning emissions are critical to characterizing air quality problems, understanding in situ measurements, and simulating chemistry and climate.

There have been many efforts to estimate the emissions of trace gases and particles from fires. Emissions from individual fire events have been calculated using site-specific information (e.g., the 2002 Biscuit Fire in Oregon, Campbell et al., 2007; the 2003 fires in Southern California, Muhle et al., 2007). Regional emission estimates have been created for specific time periods: for example, Michel et al. (2005) produced a fire emissions inventory for Asia for March-May 2001 in support of a major field campaign. Other inventories predict regional emissions over longer time periods (e.g., Lavoue et al., 2000; Soja et al., 2004; Wiedinmyer et al., 2006; Larkin et al., 2009).

At the global scale, several bottom-up biomass burning emissions inventories exist. Using literature emission factors and the biomass burned estimates of Yevich and Logan (2003) (obtained as described by Lobert et al., 1999), Andreae and Merlet (2001) estimated the total global emissions of many gaseous and particulate species representative of the late 1990s. Duncan et al. (2003) estimated global CO emissions from biomass burning for multiple years (19962000) and evaluated the regional and interannual variability in the emissions. Using a combination of satellite-derived datasets, Ito and Penner (2004) developed a monthly fire emissions inventory at a high spatial resolution $(1 \mathrm{~km})$ for the year 2000. Hoelzemann et al. (2004) also estimated global biomass burning emissions of trace gases and particles for 2000, using their Global Wildland Fire Emission Model (GWEM). GWEM is based on the European Space Agency's monthly Global Burn Scar satellite product (GLOBSCAR) and results from the Lund-Potsdam-Jena Dynamic Global Vegetation Model (LPJ-DGVM). The results include monthly fire emissions for 2000 at a resolution of $0.5^{\circ} \times 0.5^{\circ}$. The Fire Locating and Modeling of Burning Emissions (FLAMBE) Program (e.g., Reid et al., 2009) provides global particulate emissions from open biomass burning for use in both hindcast and operational forecasting applications. Particulate emissions have been estimated with FLAMBE for 2000 through the current day. Inverse modeling efforts have provided top down constraints on the emissions from open biomass burning. For instance, Stavrakou et al. (2009) used SCIAMACHY formaldehyde measurements from space and an inverse model to constrain global nonmethane organic compound emissions for 2003-2006, and other studies have used carbon monoxide (CO) observations from space and an inverse model to constrain the $\mathrm{CO}$ emissions from biomass burning and other sources (Arellano et al., 2004, 2006; Kopacz et al., 2010).
The Global Fire Emissions Database (GFED, Randerson et al., 2005; van der Werf et al., 2004, 2006, 2010) is a widely applied global biomass burning emissions dataset. Now in its third version, GFED includes 8-day and monthly emissions of selected trace gas and particulate emissions from burning globally at horizontal resolutions as fine as $0.5^{\circ}$ for 1997 2009 (van der Werf et al., 2006; Giglio et al., 2010; van der Werf et al., 2010). GFED is used by global chemical transport and climate modelers in efforts to understand the chemical composition of the atmosphere (e.g., Colarco et al., 2010; Nassar et al., 2009; Magi et al., 2009; Stavrakou et al., 2009). Other global inventories have been created for similar purposes. Recent work by Mieville et al. (2010) describes the Global Inventory for Chemistry-Climate Studies (GICC), which provides estimates of the emissions of $\mathrm{CO}_{2}, \mathrm{CO}, \mathrm{NO}_{\mathrm{x}}$, particulate black carbon (BC) and organic carbon (OC) from burning for historical and current time periods for use specifically in chemistry-climate modeling applications. Emissions of other key trace gas emissions from fires are also available from the GICC via the GEIAcenter.org website, but have not yet been published. Despite all of these various efforts, the uncertainty associated with open burning emissions remains high. Additionally, modelers often do not have access to emissions with the spatial and/or temporal resolution needed to accomplish the required scientific goals. We have created an emissions modeling framework that provides highly resolved emission estimates from open burning needed for some specific model applications.

Here we present a detailed description of the Fire INventory from NCAR version 1.0 (FINNv1) model, initial results from the model, a discussion of uncertainties, and a comparison to other estimates. The FINNv1 provides high resolution, global emission estimates from open burning, which is an episodic phenomenon. Estimates from trash burning or biofuel use are not included, as they are expected to be less variable and they are only amenable to estimation using other methods. FINNv1 emission estimates have been developed specifically to provide input needed for modeling atmospheric chemistry and air quality in a consistent framework at scales from local to global. The inventory framework described here produces daily emission estimates at a horizontal resolution of $\sim 1 \mathrm{~km}^{2}$. The product differs from other inventories because it provides a unique combination of high temporal and spatial resolution, global coverage, and estimates for a large number of species. Speciation profiles of the NMOC emissions are provided for three chemical mechanisms based on a new compilation of biomass burning emission factors (Akagi et al., 2011).

\section{Model description}

FINNv1 is based on the framework described earlier by Wiedinmyer et al. (2006). FINNv1 uses satellite observations of active fires and land cover, together with emission 
factors and estimated fuel loadings to provide daily, highlyresolved $(1 \mathrm{~km})$ open burning emissions estimates for use in regional and global chemical transport models. The emissions are estimated using the following equation:

$E_{i}=A(x, t) \times B(x) \times \mathrm{FB} \times \mathrm{ef}_{i}$

Where the emission of species $i$ ( $E_{i}$, mass of $i$ emitted) is equal to the area burned at time $t$ and location $x[(A(x, t)]$ multiplied by the biomass loading at location $x[B(x)]$, the fraction of that biomass that is burned in the fire (FB), and the emission factor of species $i$ (ef $f_{i}$, mass of $i$ emitted/mass of biomass burned). All biomass terms are on a dry weight basis.

FINNv1 has been designed to use any fire detection data available. However, for the default model described here, the location and timing for the fires are identified globally by the MODIS Thermal Anomalies Product (Giglio et al., 2006). This product provides detections of active fires based on observations from the MODIS instruments onboard the NASA Terra and Aqua polar orbiting satellites. Processed fire detections, from the MODIS Rapid Response (MRR) or the MODIS Data Processing System (MODAPS) Collection 5, are obtained directly from the University of Maryland (NASA/University of Maryland, 2002; Davies et al., 2009). (For more information about these data, refer to the MODIS Fire Users Guide, http://maps.geog.umd.edu/ products/MODIS_Fire_Users_Guide_2.4.pdf, and the FAQ section, http://maps.geog.umd.edu/firms/faq.htm). These data provide daily fire detections with a nominal horizontal resolution of $\sim 1 \mathrm{~km}^{2}$ and include the location and overpass time (UTC) of the fire detection and the confidence of the fire detection. Despite the uncertainties associated with the daily fire detections (see Uncertainties Section below), they are used specifically to capture the day to day fluctuation in fire emissions that are critical for many applications. All fire detections from the MODIS instruments aboard both the NASA Aqua and Terra satellites from 1 January 2005 through 31 December 2010 are used here. Fire detections with confidence less than $20 \%$ are removed. For 2005-2010, annually $\sim 2 \%$ of the original fire points are removed due to low confidence values.

The MODIS satellite observations do not cover the entire globe daily at latitudes between approximately $30^{\circ} \mathrm{N}$ and $30^{\circ} \mathrm{S}$, due to the observational swath path. Since forecasting and air quality applications require daily emission estimates, the detections are smeared over two days. To accommodate for the lack of daily coverage in the tropical latitudes, fire detections in these equatorial regions are counted for a 2-day period, following methods similar to those described by AlSaadi et al. (2008). For each fire detected in the equatorial region only, a fire is assumed to continue into the next day at half of its original size. This assumption has yet to be verified. Once the potential gaps in tropical fires are considered, multiple daily detections of individual fires are removed as described next.
Since observations from both MODIS instruments aboard the Terra and Aqua satellites are applied, the possibility of "double-counting" the same fire on a single day occurs. Therefore, for each day, multiple detections of the same fire pixel are identified globally and removed as described by AlSaadi et al. (2008). This method removes fire detections for a single day that fall within a $1 \mathrm{~km}^{2}$ radius of another fire detection. Therefore, for each $1 \mathrm{~km}^{2}$ hot spot, there can be only one fire per day. If a fire occurs the following day at the same location, it is counted again. Therefore, fires that prevail in the same location over several days are accounted for.

The type of vegetation burned at each fire pixel is determined by the MODIS Collection 5 Land Cover Type (LCT) product for 2005 (Friedl et al., 2010). The IGBP land cover classification (Table 1) is used to assign each fire pixel to one of 16 land cover/land use (LULC) classes. Additionally, at each fire point, the MODIS Vegetation Continuous Fields (VCF) product (Collection 3 for 2001) is used to identify the density of the vegetation at each active fire location. The VCF product identifies the percent tree, non-tree vegetation, and bare cover at $500 \mathrm{~m}$ resolution (Hansen et al., 2003, 2005; Carroll et al., 2011). The VCF data are scaled to $1 \mathrm{~km}$ spatial resolution to match the fire detection and LCT datasets.

Inconsistencies between the datasets described above are resolved as follows. Any fire detections in areas with the LCT classification for water, snow, or ice are removed $(<0.2 \%$ of original annual fire points). When the total cover from the VCF product for any fire point does fully cover each pixel, the values are scaled to $100 \%$. This primarily happens as a result of the scaling of the VCF product from $500 \mathrm{~m}$ to $1 \mathrm{~km}$ resolution. Those fire detections that fall in areas that are $100 \%$ bare cover or unclassified according to the VCF product are reassigned vegetation coverage based on the LCT classification (typically $<0.5 \%$ of original annual fire detections). In these cases, for fires located on LCT forest classifications, the percent coverage is reassigned to $60 \%$ tree cover and $40 \%$ herbaceous cover. For fires in LCT shrubland classifications, the percent cover is reassigned to $50 \%$ tree cover and $50 \%$ herbaceous cover. For fires in LCT grassland classifications that do not have associated VCF cover information, the percent vegetative cover is reassigned to $20 \%$ tree cover and $80 \%$ herbaceous cover.

Fire points assigned by the LCT product as "urban" or "bare/sparsely vegetated" are assumed to be open vegetation burning and are reassigned a land cover type based on the total tree and non-tree vegetation cover, as determined by the VCF product. For those fire points with less than $40 \%$ tree cover, the urban or sparsely vegetated land cover is reassigned to grasslands; for $40-60 \%$ tree cover, the point is reassigned as shrublands; and for tree cover greater than $60 \%$ tree cover, the point is reassigned as a forest.

The global LULC classifications of the MODIS LCT product are then further lumped into more generic land cover classifications that better match available information on global 
Table 1. Land use/land cover classifications as assigned by the MODIS Land Cover Type, assigned generic land cover class, and emission factors ( $\mathrm{g} \mathrm{kg}$ Biomass Burned ${ }^{-1}$ ). Sources of emission factors are by color.

\begin{tabular}{|c|c|c|c|c|c|c|c|c|c|c|c|c|c|c|c|c|c|}
\hline $\begin{array}{l}\text { LCT } \\
\text { Classification }\end{array}$ & $\begin{array}{l}\text { Generic } \\
\text { Vegetation Type }\end{array}$ & $\mathrm{CO}_{2}$ & $\mathrm{CO}$ & $\mathrm{CH}_{4}$ & $\mathrm{H}_{2}$ & $\begin{array}{c}\mathrm{NO}_{\mathrm{x}} \\
\text { (as NO) }\end{array}$ & NO & $\mathrm{NO}_{2}$ & NMOC & NMHC & $\mathrm{SO}_{2}$ & $\mathrm{NH}_{3}$ & $\mathrm{PM}_{2.5}$ & TPM & TPC & $\mathrm{OC}$ & $\mathrm{BC}$ \\
\hline Evergreen Needleleaf Forest & BOR & 1514 & 118 & 6 & 2.3 & 1.8 & 1.5 & 3 & 28 & 5.7 & 1 & 3.5 & 13 & 18 & 8.3 & 7.8 & 0.2 \\
\hline Evergreen Broadleaf Forest & TROP & 1643 & 92 & 5.1 & 3.2 & 2.6 & 0.91 & 3.6 & 24 & 1.7 & 0.45 & 0.76 & 9.7 & 13 & 5.2 & 4.7 & 0.52 \\
\hline Deciduous Needleleaf Forest & BOR & 1514 & 118 & 6 & 2.3 & 3 & 1.5 & 3 & 28 & 5.7 & 1 & 3.5 & 13 & 18 & 8.3 & 7.8 & 0.2 \\
\hline Deciduous Broadleaf Forest & TEMP & 1630 & 102 & 5 & 1.8 & 1.3 & 0.34 & 2.7 & 11 & 5.7 & 1 & 1.5 & 13 & 18 & 9.7 & 9.2 & 0.56 \\
\hline Mixed Forests & TEMP & 1630 & 102 & 5 & 1.8 & 1.3 & 0.34 & 2.7 & 14 & 5.7 & 1 & 1.5 & 13 & 18 & 9.7 & 9.2 & 0.56 \\
\hline Closed Shrublands & WS & 1716 & 68 & 2.6 & 0.97 & 3.9 & 1.4 & 1.4 & 4.8 & 3.4 & 0.68 & 1.2 & 9.3 & 15.4 & 7.1 & 6.6 & 0.5 \\
\hline Open Shrublands & WS & 1716 & 68 & 2.6 & 0.97 & 3.9 & 1.4 & 1.4 & 4.8 & 3.4 & 0.68 & 1.2 & 9.3 & 15.4 & 7.1 & 6.6 & 0.5 \\
\hline Woody Savannas & WS & 1716 & 68 & 2.6 & 0.97 & 3.9 & 1.4 & 1.4 & 4.8 & 3.4 & 0.68 & 1.2 & 9.3 & 15.4 & 7.1 & 6.6 & 0.5 \\
\hline Savannas & SG & 1692 & 59 & 1.5 & 0.97 & 2.8 & 0.74 & 3.2 & 9.3 & 3.4 & 0.48 & 0.49 & 5.4 & 8.3 & 3 & 2.6 & 0.37 \\
\hline Grasslands & SG & 1692 & 59 & 1.5 & 0.97 & 2.8 & 0.74 & 3.2 & 9.3 & 3.4 & 0.48 & 0.49 & 5.4 & 8.3 & 3 & 2.6 & 0.37 \\
\hline Permanent Wetlands & SG & 1692 & 59 & 1.5 & 0.97 & 2.8 & 0.74 & 3.2 & 9.3 & 3.4 & 0.48 & 0.49 & 5.4 & 8.3 & 3 & 2.6 & 0.37 \\
\hline Croplands & CROP & 1537 & 111 & 6 & 2.4 & 3.5 & 1.7 & 3.9 & 57 & 7 & 0.4 & 2.3 & 5.8 & 13 & 4 & 3.3 & 0.69 \\
\hline Cropland/Natural Vegetation Mosaic & SG & 1692 & 59 & 1.5 & 0.97 & 2.8 & 0.74 & 3.2 & 9.3 & 3.4 & 0.48 & 0.49 & 5.4 & 8.3 & 3 & 2.6 & 0.37 \\
\hline Barren or Sparsely Vegetated & SG & 1692 & 59 & 1.5 & 0.97 & 2.8 & 0.74 & 3.2 & 9.3 & 3.4 & 0.48 & 0.49 & 5.4 & 8.3 & 3 & 2.6 & 0.37 \\
\hline
\end{tabular}

BOR $=$ Boreal Forest; TROP $=$ Tropical Forest TEMP $=$ Temperate Forest WS $=$ Woody Savannah $/$ Shrubland; $\mathrm{SG}=\mathrm{Savanna} / \mathrm{Grass}$ land $;$ CROP $=$ Croplands Sources for Emission Factors

\begin{tabular}{l}
\hline Andreae (2008), Extratropical Forest \\
Akagi et al. (2011) \\
McMeeking (2008) \\
Andreae and Merlet (2001) Savanna \& Grassland \\
Calculate $\mathrm{NO}_{2}$ EF from $\mathrm{NO}_{\mathrm{x}}$ and NO EFs \\
Andreae and Merlet (2001) Crop Residue \\
Sum of OC and BC EFs
\end{tabular}

fuel loadings and emission factors. These generic categories include Savanna and Grasslands (SG), Woody Savannas and Shrublands (WS), Tropical Forest (TROP), Temperate Forest (TEMP), Boreal Forest (BOR), and Cropland (CROP) (Table 1). The evergreen, deciduous, and mixed forest land covers of the LCT are assigned as either boreal or temperate forest depending on the latitude of the point: if latitude is greater than $50^{\circ} \mathrm{N}$, the forest is labeled as a boreal forest.

At present, FINNv1 does not obtain the area burned at each identified fire pixel from burned area products since they are not rapidly available. Therefore, an upper limit is assumed for the burned area. For each fire identified, the assumed burned area is $1 \mathrm{~km}^{2}$, except for fires located in grasslands/savannas: these are assigned a burned area of $0.75 \mathrm{~km}^{2}$ (Wiedinmyer et al., 2006; Al-Saadi et al., 2008). This burned area is further scaled based on the percent bare cover by the VCF product at the fire point. For example, a forest fire detected at a point is assigned a burned area of $1 \mathrm{~km}^{2}$; yet, if that same pixel is assigned $50 \%$ bare cover by the VCF dataset, the assigned burned area is $0.5 \mathrm{~km}^{2}$.

Fuel loadings (or the amount of biomass available that can be burned in each fire) for each generic LULC in the various world regions are assigned based on values from Table 2 of Hoelzemann et al. (2004) and updates shown in our Table 2. For most classes and regions, the average of the GWEM v1.2 and v1.21 are used (Hoelzemann et al., 2004). Changes to the original values presented by Hoelzemann et al. (2004) include the following: (1) temperate forests in Oceana are assigned the average of the fuel loadings for temperate and tropical forests assigned by Hoelzemann et al. (2004)for that region. (2) The temperate forest fuel loading for Australia, particularly in the eucalyptus forests of southeastern Australia, is typically much higher than the $7000 \mathrm{~g} \mathrm{~m}^{-2}$ assigned by Hoelzemann et al. (2004) (C. Murphy, personal communications) and is been replaced with a larger value. (3) The fuel loading assigned to croplands is $500 \mathrm{~g} \mathrm{~m}^{-2}$ for fires assigned to croplands (Wiedinmyer et al., 2006). We expect that the North America fuel load of $500 \mathrm{~g} \mathrm{~m}^{-2}$ is towards the lower limit and would result in a conservative global crop residue fuel load. The one exception to this rule is for a small area of croplands within Brazil (from latitude $20.36^{\circ}$ to $22.71^{\circ} \mathrm{S}$ and longitude $-47.32^{\circ}$ and $-49.16^{\circ} \mathrm{W}$ ). In this limited region, sugar cane is assumed to be the crop type that is burned, and the fuel loading here is assigned as $1100 \mathrm{~g} \mathrm{~m}^{-2}$ (Macedo et al., 2008; E. Campbell, personal communications, June 2010). This is just one example of how the model can be modified at regional and local levels to include specific information.

The fraction of the biomass assumed to burn (FB) at each fire point is assigned as a function of tree cover, as described by Wiedinmyer et al. (2006) and taken from Ito and Penner (2004). For areas with $60 \%$ or more tree cover, as defined by the MODIS VCF product, FB is 0.3 for the woody fuel and 0.9 for the herbaceous cover. For areas with less than $40 \%$ tree cover, no woody fuel is assumed to burn and the FB is 0.98 for the herbaceous cover. Note that these are the upper limits as presented by Ito and Penner (2004). For those fires with $40-60 \%$ tree cover, FB is 0.3 for the woody fuels, and FB for the herbaceous fuel is calculated as:

$\mathrm{FB}_{\text {herbaceous_fuel }}=e^{-0.13 \times \text { fraction_tree_cover }}$. 
Table 2. Fuel loadings $\left(\mathrm{g} \mathrm{m}^{-2}\right)$ assigned to generic land cover classifications for the global regions. These values are based on the average of the two model estimates from Table 2 of Hoelzemann et al. (2004) unless noted otherwise.

\begin{tabular}{lrrrrr}
\hline $\begin{array}{l}\text { Global } \\
\text { Region }\end{array}$ & $\begin{array}{r}\text { Tropical } \\
\text { Forest }\end{array}$ & $\begin{array}{r}\text { Temperate } \\
\text { Forest }\end{array}$ & $\begin{array}{r}\text { Boreal } \\
\text { Forest }\end{array}$ & $\begin{array}{r}\text { Woody Savanna/ } \\
\text { Shrublands }\end{array}$ & $\begin{array}{r}\text { Savanna and } \\
\text { Grasslands }\end{array}$ \\
\hline North America & $28076^{\mathrm{b}}$ & 10492 & $25000^{\mathrm{a}}$ & 5705 & 976 \\
Central America & 20260 & $11000^{\mathrm{a}}$ & & 2224 & 418 \\
South America & 25659 & $7400^{\mathrm{a}}$ & & 3077 & 552 \\
Northern Africa & 25366 & 3497 & & 2501 & 318 \\
Southern Africa & 25295 & 6100 & & 2483 & 360 \\
Western Europe & $28076^{\mathrm{b}}$ & 7120 & 6228 & 4523 & 1321 \\
Eastern Europe & $28076^{\mathrm{b}}$ & 11386 & 8146 & 7752 & 1612 \\
NorthCentral Asia & $6181^{\mathrm{c}}$ & 20807 & $25000^{\mathrm{a}}$ & 11009 & 2170 \\
Near East & $6181^{\mathrm{c}}$ & 10316 & & 2946 & 655 \\
East Asia & $6181^{\mathrm{c}}$ & 7865 & & 4292 & 722 \\
Southern Asia & 27969 & 14629 & & 5028 & 1445 \\
Oceania & 16376 & $11696^{\mathrm{d}}$ & & 1271 & 245 \\
\hline
\end{tabular}

${ }^{a}$ Akagi et al. (2011) and references therein; ${ }^{b}$ added a tropical forest class to North America and Europe (in LCT); ${ }^{\mathrm{a}}$ all Asia assigned equal tropical forest values; ${ }^{\mathrm{d}}$ taken as the average of tropical and temperate forest fuel loadings for Oceania.

The amount of woody fuel available to burn at each fire is determined by the fraction of tree cover and the fuel loading for the specific land cover type and global region; the herbaceous fuel loading is assigned the fuel loading for the grassland land cover in that global region. The amount of the fuel burned is equal to the biomass loading multiplied by the fraction burned and the fractional cover of each vegetation cover (by the MODIS VCF) for each pixel.

For each LULC type, the emission factors for various gaseous and particulate species have been taken from available datasets (see Table 1 and references therein). Detailed emission factors for individual NMOCs emitted by open burning have been compiled by Akagi et al. (2011), Andreae and Merlet (2001), and M. O. Andreae (personal communication, October 2008). However, to simulate NMOC chemistry in many models, particularly chemical transport models, many of the individual chemical compounds are assigned to "lumped" species in a simplified chemical mechanism. FINNv1 calculates both the total NMOC for each generic land cover type, and also lumps the total NMOC emissions as appropriate for various chemical mechanisms. Tables 3-5 include speciation factors developed from the species-specific emissions factors provided by Akagi et al. (2011), Andreae and Merlet (2001), McMeeking (2008), and M. O. Andreae (personal communication, October 2008). Multiplying the total NMOC emissions (kg) from FINNv1 by the speciation factors shown in the Tables will provide the moles emitted of individual organic compounds or lumped species for the indicated chemical mechanism. Here we provide speciation profiles for the GEOS-Chem (Bey et al., 2001; http://www.geos-chem.org/), MOZART-4 (Emmons et al., 2010a), and SAPRC99 (Carter et al., 2000) chemical mechanisms. These speciation profiles are available for use not only with FINNv1 emission estimates, but also other NMOC fire emission estimates from other fire models.

The primary differences in the methods described here, compared to the framework presented by Wiedinmyer et al. (2006), include the extension of the model domain from North and Central America to the globe; the removal of fire detections with confidence less than $20 \%$; the "smoothing" of the fire detections in the tropical latitudes where satellite observations occur less than daily; the removal of multiple detections of the same fire for a given day; the use of the MODIS Land Cover Type dataset to describe the ecosystem burned; and the updated emission factors from the most recent datasets. For North and Central America, the model improvements in FINNv1 lead to significant differences between the results obtained from earlier versions of this model framework (e.g., Wiedinmyer at al., 2006; Wiedinmyer and Neff, 2007).

\section{Results}

Daily fire emissions for 1 January 2005 through 31 December 2010 were estimated using the FINNv1 model framework and inputs described here. The daily global results for the MOZART-4 and SAPRC99 chemical mechanisms are available for download and use at http://bai.acd.ucar.edu/Data/ fire/. The global total emissions of key trace gases and particulate species for each year from 2005-2010 are shown in Table 6. Table 7 shows the annual, global biomass and area burned by generic land cover type for 2005-2010. Annual average (2005-2010) regional estimates of emissions, burn area, and biomass burned are provided in Table 8 for regions shown in Fig. 1 (adapted from van der Werf et al., 2006; 2010). The results show a significant variation in the global 


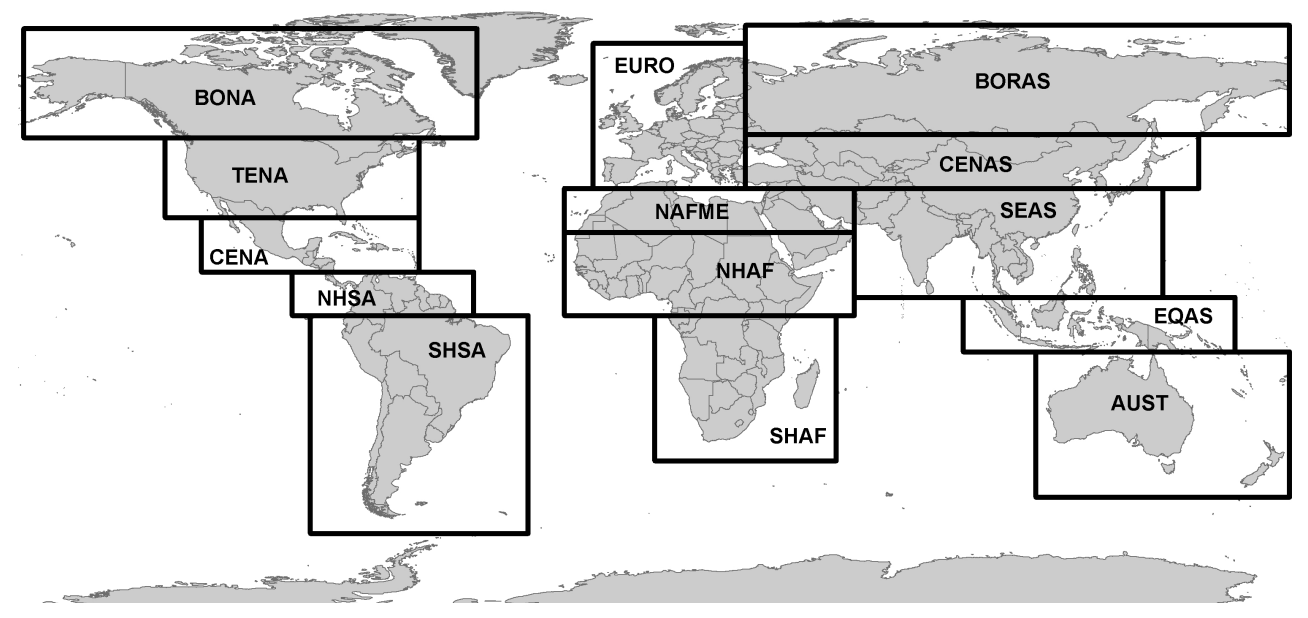

Fig. 1. Regions used for analysis, taken from those applied by van der Werf et al. (2006, 2010). The acronyms on the figure represent the following: BONA: Boreal North America; TENA: Temperate North America; CENA: Central America and Mexico; NHSA: Northern Hemispheric South America; SHSA: Southern Hemispheric South America; SHAF: Southern Hemispheric Africa; NHAF: Northern Hemispheric Africa; NAFME: Northern Africa and the Middle East; EURO: Europe; AUSTR: Australia; EQAS: Equatorial Asia; SEAS: Southeast Asia and India; CENAS: Central Asia; BORAS: Boreal Asia.

annual totals, and substantial spatial variability in the regional estimates. For the years investigated, equatorial Asia (EQAS) has the most variability in area and biomass burned and resulting emissions. The tropical forests produce the highest annual emissions, followed by shrublands and woody savannas (Fig. 2). The tropical forests produce the highest emissions because the number of hot spots in the tropical forests is the highest, and the amount of biomass burned in these fires is also higher than other fuel types. The majority of the emissions of $\mathrm{CO}$ from cropland fires occur in the Northern Hemisphere.

\subsection{Comparison of FINNv1 to other biomass burning inventories}

On a global scale, the biomass consumption and total emissions predicted with FINNv1 are fairly similar to amounts from other global estimates. For example, the total global biomass burned in GICC (Mieville et al., 2010) for 2000 was estimated to be $5790 \mathrm{Tg}$, and the average annual global biomass burned from 2005-2010 estimated with FINNv1 is $5720 \mathrm{Tg}$ (Table 7) The global annual FINNv1 $\mathrm{CO}_{2}$ emission estimates are $\sim 5-30 \%$ larger than the GFEDv3.1 estimates (Table 9). The agreement is variable by year and the differences result primarily from the different fuel consumption approaches that drive the two models. Regionally, these differences between FINNv1 and GFEDv3.1 are not consistent. Using regions similar to those applied by van der Werf et al. (2006) (Fig. 1), annual average (20052009) $\mathrm{CO}_{2}$ emissions from the two approaches are compared (Fig. 3). FINNv1 predicts higher emissions in South America and Southeast Asia, whereas GFEDv3.1 produces higher estimates in Africa and boreal North America. The lower

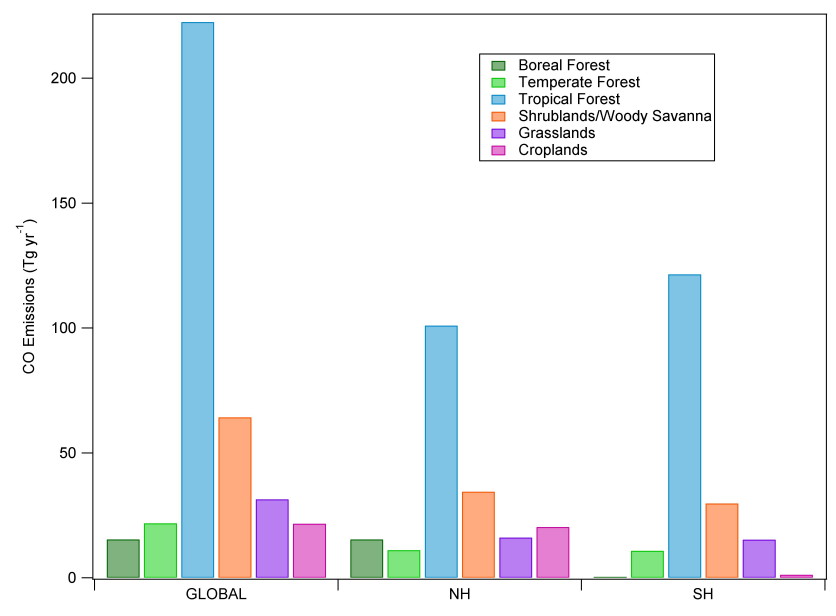

Fig. 2. FINNv1 emission estimates of CO averaged over 20052010 for the five generic land cover types. Totals are given for the globe, for the Northern Hemisphere (NH), and for the Southern Hemisphere $(\mathrm{SH})$.

FINNv1 emission estimates in Africa could be the result of an underestimate of the area burned in this region in that the assumed burn area per hot spot could be too low for savannah fires. These regions of discrepancy may be those for which further validation is most warranted for the two methods.

Next we compare the detailed emissions of various, mostly reactive, species. For 2005, the GICC estimates $504 \mathrm{Tg} \mathrm{CO}$, $20.5 \mathrm{Tg} \mathrm{NO}_{\mathrm{x}}\left(\right.$ as $\mathrm{NO}_{2}$ ), and 3.8 Tg BC for 2005. FINNv1 estimates for these compounds for 2005 are $375 \mathrm{Tg} \mathrm{CO}$, $20.4 \mathrm{Tg} \mathrm{NO}_{\mathrm{x}}$ (as $\mathrm{NO}_{2}$ ), and $2.3 \mathrm{Tg} \mathrm{BC}$. The average annual $\mathrm{PM}_{2.5}$ estimate from FINNv1 (2006-2008) was $40 \mathrm{Tg}$, 
Table 3. Factors to convert NMOC Emissions $\left(\mathrm{kg} \mathrm{day}^{-1}\right)$ to MOZART-4 chemical species (moles-species day ${ }^{-1}$ ) for each generic land cover class in which a fire burns. See Emmons et al. (2010a) for description of lumped species.

\begin{tabular}{|c|c|c|c|c|c|c|}
\hline \multirow[b]{2}{*}{$\begin{array}{l}\text { MOZART } 4 \\
\text { Species }\end{array}$} & \multicolumn{2}{|c|}{ Generic Land Cover Type } & \multirow[b]{2}{*}{$\begin{array}{r}\text { Temperate } \\
\text { Forest }\end{array}$} & \multirow[b]{2}{*}{ Agriculture } & \multirow[b]{2}{*}{$\begin{array}{l}\text { Boreal } \\
\text { Forest }\end{array}$} & \multirow[b]{2}{*}{ Shrublands } \\
\hline & $\begin{array}{r}\text { Savanna/ } \\
\text { Grasslands }\end{array}$ & $\begin{array}{r}\text { Tropical } \\
\text { Forest }\end{array}$ & & & & \\
\hline BIGALD & 0.02 & 0.01 & 0.01 & 0.01 & 0.01 & 0.02 \\
\hline BIGALK & 0.20 & 0.13 & 0.11 & 0.09 & 0.16 & 0.42 \\
\hline BIGENE & 0.45 & 0.52 & 0.22 & 0.37 & 0.35 & 0.63 \\
\hline $\mathrm{C}_{10} \mathrm{H}_{16}$ & 0.01 & 0.04 & 0.03 & 0.00 & 0.04 & 0.01 \\
\hline $\mathrm{C}_{2} \mathrm{H}_{4}$ & 2.27 & 1.38 & 1.11 & 1.08 & 1.62 & 2.30 \\
\hline $\mathrm{C}_{2} \mathrm{H}_{5} \mathrm{OH}$ & 0.02 & 0.01 & 0.01 & 0.01 & 0.01 & 0.02 \\
\hline $\mathrm{C}_{2} \mathrm{H}_{6}$ & 0.82 & 0.82 & 0.29 & 0.43 & 1.63 & 1.01 \\
\hline $\mathrm{C}_{3} \mathrm{H}_{6}$ & 0.43 & 0.56 & 0.26 & 0.38 & 0.76 & 0.77 \\
\hline $\mathrm{C}_{3} \mathrm{H}_{8}$ & 0.18 & 0.10 & 0.10 & 0.08 & 0.13 & 0.37 \\
\hline $\mathrm{CH}_{2} \mathrm{O}$ & 2.12 & 2.08 & 1.33 & 1.84 & 1.46 & 2.23 \\
\hline $\mathrm{CH}_{3} \mathrm{CHO}$ & 1.03 & 1.27 & 0.38 & 3.05 & 0.67 & 0.96 \\
\hline $\mathrm{CH}_{3} \mathrm{CN}$ & 0.21 & 0.36 & 0.12 & 0.55 & 0.13 & 0.41 \\
\hline $\mathrm{CH}_{3} \mathrm{COCH}_{3}$ & 0.22 & 0.39 & 0.20 & 0.83 & 0.20 & 0.71 \\
\hline $\mathrm{CH}_{3} \mathrm{COCHO}$ & 0.81 & 0.37 & 0.17 & 0.19 & 0.28 & 0.86 \\
\hline $\mathrm{CH}_{3} \mathrm{COOH}$ & 2.08 & 1.87 & 0.53 & 2.19 & 1.80 & 1.24 \\
\hline $\mathrm{CH}_{3} \mathrm{OH}$ & 1.92 & 2.60 & 1.51 & 2.11 & 2.50 & 2.49 \\
\hline CRESOL & 0.44 & 0.17 & 0.07 & 0.60 & 0.85 & 0.00 \\
\hline GLYALD & 0.50 & 0.79 & 0.28 & 1.68 & 0.25 & 1.39 \\
\hline $\mathrm{HCN}$ & 1.01 & 0.56 & 0.51 & 0.33 & 2.49 & 1.29 \\
\hline HYAC & 1.01 & 0.55 & 8.03 & 0.00 & 0.77 & 0.00 \\
\hline ISOP & 0.05 & 0.07 & 0.03 & 0.60 & 0.14 & 0.03 \\
\hline MACR & 0.00 & 0.08 & 0.00 & 0.00 & 0.00 & 0.00 \\
\hline MEK & 1.31 & 0.85 & 0.41 & 0.79 & 1.64 & 1.16 \\
\hline MVK & 0.00 & 0.20 & 0.00 & 0.00 & 0.00 & 0.00 \\
\hline NO & 0.38 & 0.74 & 0.26 & 0.09 & 0.70 & 0.74 \\
\hline TOLUENE & 1.16 & 2.06 & 0.61 & 1.07 & 1.30 & 1.32 \\
\hline $\mathrm{HCOOH}$ & 0.65 & 0.44 & 0.26 & 0.90 & 0.57 & 0.16 \\
\hline $\mathrm{C}_{2} \mathrm{H}_{2}$ & 0.72 & 0.36 & 0.14 & 0.21 & 0.20 & 0.55 \\
\hline
\end{tabular}

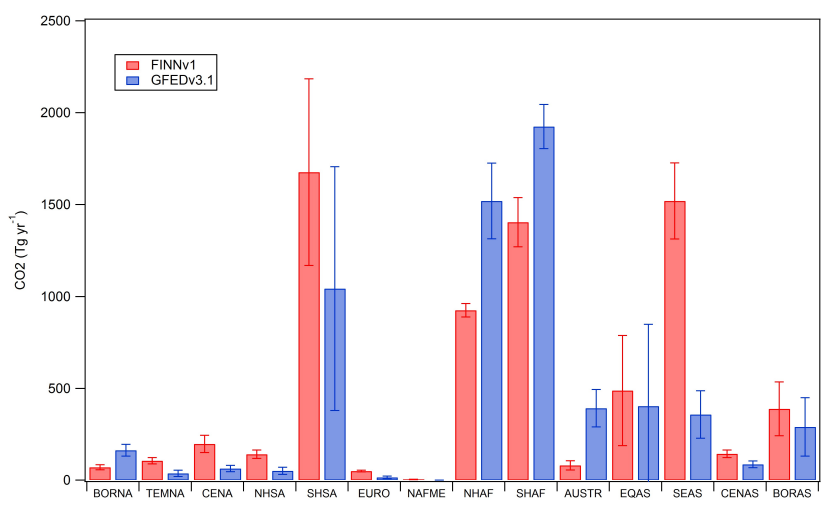

Fig. 3. Annual average $\mathrm{CO}_{2}$ emissions (2005-2009) for FINNv1 and GFED3.1 for regions shown in Fig. 1. Error bars represent the standard deviation of the annual estimates. whereas this number was $44 \mathrm{Tg}$ from GFEDv2 and $110 \mathrm{Tg}$ from FLAMBE (Reid et al., 2009). The different estimates for the above species are consistent within the uncertainties of the model frameworks (see Sect. 3.5).

The organic compounds emitted by fires are reactive species that play a role in the formation of ozone and secondary organic aerosol. Thus, accurate estimates of the organic emissions from open burning are critical input for any atmospheric chemistry or air quality model. Comparison of organic emissions derived from FINNv1 with previous biomass burning estimates or with other sources of organic emissions (Sect. 3.2) requires clarification of the relevant terminology, which is also discussed in more detail in Akagi et al. (2011). Non-methane hydrocarbons (NMHC) are organic molecules that by definition contain only atoms of $\mathrm{C}$ and $\mathrm{H}$ such as alkenes and alkanes. In early biomass burning research, NMHC were thought to account for nearly all the organic compounds emitted by fires and it became 
Table 4. Factors to convert NMOC Emissions $\left(\mathrm{kg} \mathrm{day}^{-1}\right.$ ) to SAPRC99 chemical species (moles-species day ${ }^{-1}$ ) for each generic land cover class in which a fire burns.

\begin{tabular}{|c|c|c|c|c|c|c|}
\hline \multirow[b]{2}{*}{$\begin{array}{l}\text { SAPRC99 } \\
\text { Species }\end{array}$} & \multicolumn{3}{|c|}{ Generic Land Cover Type } & \multirow[b]{2}{*}{ Cropland } & \multirow[b]{2}{*}{$\begin{array}{l}\text { Boreal } \\
\text { Forest }\end{array}$} & \multirow[b]{2}{*}{ Shrublands } \\
\hline & $\begin{array}{l}\text { Savanna/ } \\
\text { Grasslands }\end{array}$ & $\begin{array}{r}\text { Tropical } \\
\text { Forest }\end{array}$ & $\begin{array}{r}\text { Temperate } \\
\text { Forest }\end{array}$ & & & \\
\hline ACET & 0.22 & 0.40 & 0.20 & 0.83 & 0.20 & 0.71 \\
\hline ALK1 & 1.25 & 1.40 & 0.47 & 1.22 & 1.84 & 1.63 \\
\hline ALK2 & 0.92 & 0.51 & 0.26 & 0.31 & 0.34 & 1.12 \\
\hline ALK3 & 0.04 & 0.04 & 0.03 & 0.02 & 0.05 & 0.05 \\
\hline ALK4 & 0.07 & 0.04 & 0.04 & 0.03 & 0.06 & 0.10 \\
\hline ALK5 & 0.06 & 0.03 & 0.02 & 0.02 & 0.03 & 0.06 \\
\hline ARO1 & 1.11 & 1.86 & 0.53 & 0.95 & 1.18 & 1.24 \\
\hline $\mathrm{ARO} 2$ & 0.03 & 0.08 & 0.06 & 0.06 & 0.10 & 0.06 \\
\hline BALD & 0.02 & 0.12 & 0.01 & 0.01 & 0.01 & 0.02 \\
\hline $\mathrm{CCHO}$ & 1.03 & 1.31 & 0.38 & 3.05 & 0.67 & 0.95 \\
\hline CCO_OH & 2.08 & 1.93 & 0.53 & 2.19 & 1.80 & 1.24 \\
\hline ETHENE & 2.27 & 1.42 & 1.11 & 1.09 & 1.61 & 2.29 \\
\hline $\mathrm{HCHO}$ & 2.11 & 2.14 & 1.33 & 1.84 & 1.45 & 2.22 \\
\hline $\mathrm{HCN}$ & 1.01 & 0.58 & 0.51 & 0.33 & 2.48 & 1.28 \\
\hline $\mathrm{HCOOH}$ & 0.65 & 0.45 & 0.26 & 0.90 & 0.57 & 0.16 \\
\hline HONO & 0.38 & 0.76 & 0.26 & 0.09 & 0.70 & 0.74 \\
\hline ISOPRENE & 0.05 & 0.07 & 0.03 & 0.60 & 0.14 & 0.03 \\
\hline MEK & 1.87 & 1.20 & 8.33 & 0.54 & 2.25 & 0.92 \\
\hline MEOH & 1.91 & 2.68 & 1.51 & 2.11 & 2.49 & 2.48 \\
\hline METHACRO & 0.00 & 0.08 & 0.00 & 0.00 & 0.00 & 0.00 \\
\hline MGLY & 0.80 & 0.38 & 0.17 & 0.19 & 0.27 & 0.86 \\
\hline MVK & 0.22 & 0.20 & 0.00 & 0.14 & 0.00 & 0.00 \\
\hline OLE1 & 0.72 & 0.83 & 0.36 & 0.54 & 0.93 & 1.06 \\
\hline OLE2 & 0.20 & 0.19 & 0.10 & 0.16 & 0.16 & 0.31 \\
\hline PHEN & 0.44 & 0.18 & 0.07 & 0.60 & 0.84 & 0.00 \\
\hline PROD2 & 0.22 & 0.23 & 0.10 & 0.11 & 0.16 & 0.24 \\
\hline RCHO & 0.60 & 1.47 & 0.36 & 2.08 & 0.37 & 1.50 \\
\hline TRP1 & 0.01 & 0.04 & 0.03 & 0.00 & 0.04 & 0.01 \\
\hline
\end{tabular}

Table 5. Factors to convert NMOC Emissions $\left(\mathrm{kg} \mathrm{day}^{-1}\right)$ to GEOS-Chem chemical species (moles-species day ${ }^{-1}$ ) for each generic land cover class in which a fire burns.

\begin{tabular}{lrrrrrr}
\hline \multirow{2}{*}{$\begin{array}{l}\text { GEOS-CHEM } \\
\text { Species }\end{array}$} & $\begin{array}{r}\text { Savanna/ } \\
\text { Grasslands }\end{array}$ & $\begin{array}{r}\text { Tropical } \\
\text { Forest }\end{array}$ & $\begin{array}{r}\text { Temperate } \\
\text { Forest }\end{array}$ & $\begin{array}{c}\text { Cropland } \\
\text { ACET }\end{array}$ & $\begin{array}{r}\text { Boreal } \\
\text { Forest }\end{array}$ & Shrublands \\
\hline ALD2 & 0.22 & 0.39 & 0.20 & 0.83 & 0.20 & 0.71 \\
$\mathrm{ALK} 4$ & 2.96 & 3.45 & 1.02 & 5.50 & 1.48 & 3.88 \\
$\mathrm{C}_{2} \mathrm{H}_{6}$ & 3.93 & 3.45 & 1.40 & 4.05 & 3.90 & 3.18 \\
$\mathrm{C}_{3} \mathrm{H}_{8}$ & 0.82 & 0.82 & 0.29 & 0.43 & 1.63 & 1.01 \\
$\mathrm{CH}_{2} \mathrm{O}$ & 0.18 & 0.10 & 0.10 & 0.08 & 0.13 & 0.37 \\
ISOP & 2.12 & 2.08 & 1.33 & 1.84 & 1.45 & 2.23 \\
$\mathrm{NO}$ & 0.06 & 0.15 & 0.08 & 0.60 & 0.23 & 0.05 \\
$\mathrm{MEK}$ & 0.38 & 0.74 & 0.26 & 0.09 & 0.70 & 0.74 \\
$\mathrm{PRPE}$ & 1.40 & 1.05 & 0.41 & 0.78 & 1.63 & 1.25 \\
$\mathrm{HCN}$ & 3.12 & 3.57 & 1.71 & 2.09 & 3.30 & 3.69 \\
& 1.02 & 0.56 & 0.51 & 0.33 & 2.49 & 1.29 \\
\hline
\end{tabular}


Table 6. Global annual emissions (Tg-Species $\mathrm{yr}^{-1}$ ) from FINNv1.

\begin{tabular}{|c|c|c|c|c|c|c|c|c|c|c|c|c|c|c|c|c|c|}
\hline YEAR & $\mathrm{CO}_{2}$ & $\mathrm{CO}$ & $\mathrm{CH}_{4}$ & NMHC & NMOC & $\mathrm{H}_{2}$ & $\mathrm{NO}_{\mathrm{x}}$ (as $\left.\mathrm{NO}\right)$ & NO & $\mathrm{NO}_{2}$ & $\mathrm{NH}_{3}$ & $\mathrm{SO}_{2}$ & $\mathrm{PM}_{2.5}$ & $\mathrm{PM}_{10}$ & TPM & TPC & $\mathrm{OC}$ & $\mathrm{BC}$ \\
\hline 2005 & 7590 & 375 & 18 & 13 & 81 & 10 & 13 & 4.6 & 13 & 4.5 & 2.5 & 42 & 51 & 60 & 25 & 23 & 2.3 \\
\hline 2006 & 7723 & 400 & 20 & 13 & 92 & 11 & 13 & 4.6 & 14 & 4.7 & 2.5 & 44 & 54 & 63 & 26 & 24 & 2.3 \\
\hline 2007 & 7275 & 372 & 18 & 13 & 81 & 10 & 12 & 4.4 & 13 & 4.4 & 2.4 & 40 & 51 & 59 & 25 & 23 & 2.2 \\
\hline 2008 & 6464 & 332 & 16 & 12 & 71 & 8.4 & 11 & 4.0 & 11 & 4.4 & 2.3 & 36 & 45 & 53 & 23 & 21 & 1.9 \\
\hline 2009 & 6886 & 347 & 17 & 12 & 75 & 9.3 & 12 & 4.2 & 12 & 4.2 & 2.3 & 39 & 48 & 56 & 24 & 22 & 2.1 \\
\hline 2010 & 7999 & 409 & 20 & 14 & 88 & 11 & 14 & 4.8 & 15 & 4.8 & 2.7 & 45 & 57 & 65 & 27 & 25 & 2.4 \\
\hline
\end{tabular}

Table 7. Global annual estimates of biomass burned $(\mathrm{Tg})$ and area burned $\left(\mathrm{km}^{2} 10^{-6}\right)$ per generic LULC type for 2005-2010.

\begin{tabular}{|c|c|c|c|c|c|c|c|c|c|c|c|c|c|c|}
\hline \multirow[b]{2}{*}{ Year } & \multicolumn{2}{|c|}{$\begin{array}{l}\text { Boreal } \\
\text { Forests }\end{array}$} & \multicolumn{2}{|c|}{$\begin{array}{l}\text { Tropical } \\
\text { Forests }\end{array}$} & \multicolumn{2}{|c|}{$\begin{array}{c}\text { Temperate } \\
\text { Forests }\end{array}$} & \multicolumn{2}{|c|}{$\begin{array}{c}\text { Woody Savannas/ } \\
\text { Shrublands }\end{array}$} & \multicolumn{2}{|c|}{ Grasslands } & \multicolumn{2}{|c|}{ Croplands } & \multicolumn{2}{|c|}{ Total } \\
\hline & $\begin{array}{r}\text { Biomass } \\
\text { Burned }\end{array}$ & $\begin{array}{r}\text { Area } \\
\text { Burned }\end{array}$ & $\begin{array}{r}\text { Biomass } \\
\text { Burned }\end{array}$ & $\begin{array}{r}\text { Area } \\
\text { Burned }\end{array}$ & $\begin{array}{r}\text { Biomass } \\
\text { Burned }\end{array}$ & $\begin{array}{r}\text { Area } \\
\text { Burned }\end{array}$ & $\begin{array}{r}\text { Biomass } \\
\text { Burned }\end{array}$ & $\begin{array}{r}\text { Area } \\
\text { Burned }\end{array}$ & $\begin{array}{r}\text { Biomass } \\
\text { Burned }\end{array}$ & $\begin{array}{r}\text { Area } \\
\text { Burned }\end{array}$ & $\begin{array}{r}\text { Biomass } \\
\text { Burned }\end{array}$ & $\begin{array}{r}\text { Area } \\
\text { Burned }\end{array}$ & $\begin{array}{r}\text { Biomass } \\
\text { Burned }\end{array}$ & $\begin{array}{r}\text { Area } \\
\text { Burned }\end{array}$ \\
\hline 2005 & 79 & 0.02 & 3288 & 0.62 & 236 & 0.17 & 1371 & 2.50 & 772 & 1.6 & 207 & 0.20 & 5951 & 5.1 \\
\hline 2006 & 193 & 0.04 & 3782 & 0.85 & 264 & 0.23 & 970 & 1.83 & 604 & 1.4 & 241 & 0.21 & 6054 & 4.6 \\
\hline 2007 & 95 & 0.02 & 3204 & 0.59 & 276 & 0.19 & 1216 & 2.22 & 727 & 1.60 & 188 & 0.17 & 5708 & 4.8 \\
\hline 2008 & 218 & 0.05 & 2349 & 0.44 & 258 & 0.18 & 1262 & 2.36 & 666 & 1.43 & 242 & 0.21 & 4998 & 4.7 \\
\hline 2009 & 95 & 0.02 & 2947 & 0.55 & 267 & 0.18 & 1258 & 2.26 & 625 & 1.34 & 202 & 0.19 & 5396 & 4.6 \\
\hline 2010 & 140 & 0.03 & 3630 & 0.66 & 277 & 0.20 & 1338 & 2.33 & 709 & 1.5 & 183 & 0.18 & 6280 & 4.9 \\
\hline
\end{tabular}

commonplace to equate NMHC emissions to total organic emissions. More recent work has shown that $60-80 \%$ of the identifiable organic compounds emitted by fires contain oxygen atoms in addition to $\mathrm{C}$ and $\mathrm{H}$ (Yokelson et al., 1996, 2008; Holzinger et al., 1999; Karl et al., 2007). A broader term for organic emissions that includes the oxygenated organic compounds (e.g. formaldehyde, methanol, etc.) is nonmethane organic compounds (NMOC). An updated compilation of EF for NMOC by Akagi et al. (2011) is incorporated into FINNv1. However, in some other estimates the term NMHC is still used and the quantity represented by this term may vary. Sometimes NMHC refers to just the molecules with $\mathrm{C}$ and $\mathrm{H}$ (van der Werf et al., 2006, 2010). In other studies, the term NMHC is not defined and thus unclear, but it may be intended to indicate the NMHC plus the other NMOC. In any case, the intent of previous work was probably to estimate total organic emissions regardless of the terminology. Here we compare the amount of identified NMOC emitted by open burning, as derived by FINNv1, to previous estimates of total organic emissions. One other clarification is worthwhile. Even in studies that measure fire emissions by Fourier transform infrared spectroscopy, mass spectrometry, and gas chromatography only about one-half of the NMOC peaks can be identified as specific compounds. The large number of unassigned peaks confirms that fires emit a substantial amount of NMOC that have not yet been identified with present technology (Christian et al., 2003; Karl et al., 2007). The amount of these unidentified compounds is uncertain and, thus, not further discussed in this paper; however, estimates of total global NMOC that include the unidentified species can be found in Akagi et al. (2011). The emissions of NMOC from FINNv1 are a factor of 3.7 to 5.0 higher than the GFEDv3.1 NMHC emission estimates, as is to be expected due to the consideration of more species of organic emissions in FINNv1 (Table 9).

\subsection{Comparison of biomass burning to other emission sources}

The open biomass burning emissions from FINNv1 for 2008 make up $27 \%$ of global particulate BC emissions, $33 \%$ of global CO emissions, and $62 \%$ of global primary particulate OC emissions; where the 2008 global totals were estimated by Emmons et al. (2010a) (Fig. 4).

Emissions of individual organic species are estimated from the total global NMOC emissions using the speciation profiles presented in Tables 3 through 5. The global annual totals of a few key organic compounds calculated with the MOZART-4 and SAPRC99 speciation profiles are shown in Table 10. Isoprene, the most abundant biogenic emission, is also emitted by open fires, but in small amounts compared to the $600 \mathrm{Tg}$ emitted from undisturbed vegetation (Guenther et al., 2006). However, the fire emissions of other individual NMOC species can be more important. Globally, the average annual methanol $\left(\mathrm{CH}_{3} \mathrm{OH}\right)$ emissions from open biomass burning are 2.8 times larger than the anthropogenic emissions of $\mathrm{CH}_{3} \mathrm{OH}$, and the emissions of formaldehyde $\left(\mathrm{CH}_{2} \mathrm{O}\right)$ are a factor of 1.4 larger than anthropogenic emissions (Emmons et al., 2010a). Note that that the above ratios compare open biomass burning to other estimates of anthropogenic emissions, and biofuel use (primarily cooking with biomass fuel) is included in the anthropogenic category. 
Table 8. Annual average emissions, area burned, and biomass burned (2005-2009) for the regions shown in Fig. 1. All emissions have the units $\mathrm{Gg} \mathrm{yr}^{-1}$, except for $\mathrm{CO}_{2}$, which has units $\mathrm{Tg}_{\mathrm{yr}}-1$. Area burned is shown in $\mathrm{km}^{2} \cdot 1 \mathrm{e}^{-3}$ and biomass burned is shown in $\mathrm{Tg} \mathrm{yr}^{-1}$.

\begin{tabular}{|c|c|c|c|c|c|c|c|c|c|c|c|c|c|c|c|c|}
\hline REGION & $\mathrm{CO}_{2}$ & $\mathrm{CO}$ & $\mathrm{CH}_{4}$ & NMOC & NMHC & $\begin{array}{r}\mathrm{NO}_{\mathrm{x}} \\
\text { (as NO) }\end{array}$ & $\mathrm{NO}$ & $\mathrm{NO}_{2}$ & $\mathrm{NH}_{3}$ & $\mathrm{SO}_{2}$ & $\mathrm{PM}_{2.5}$ & TPM & $\mathrm{OC}$ & $\mathrm{BC}$ & $\begin{array}{r}\text { Area } \\
\text { Burned }\end{array}$ & $\begin{array}{l}\text { Biomass } \\
\text { Burned }\end{array}$ \\
\hline BORNA & 77 & 5275 & 260 & 1159 & 260 & 110 & 70 & 134 & 144 & 45 & 592 & 849 & 367 & 14 & 18 & 49 \\
\hline TEMNA & 104 & 5902 & 275 & 1223 & 304 & 156 & 65 & 181 & 111 & 48 & 641 & 956 & 405 & 29 & 45 & 66 \\
\hline CENA & 189 & 10048 & 512 & 2252 & 316 & 312 & 109 & 357 & 110 & 63 & 1097 & 1565 & 611 & 59 & 121 & 153 \\
\hline NHSA & 147 & 7285 & 357 & 1650 & 208 & 247 & 82 & 287 & 69 & 43 & 773 & 1092 & 400 & 43 & 90 & 118 \\
\hline SHSA & 1753 & 93348 & 4865 & 22124 & 2379 & 2784 & 945 & 3599 & 858 & 528 & 9971 & 13721 & 5132 & 538 & 655 & 1410 \\
\hline EURO & 47 & 2688 & 128 & 924 & 156 & 91 & 38 & 92 & 49 & 16 & 219 & 386 & 134 & 16 & 21 & 29 \\
\hline NAFME & 4 & 183 & 7 & 44 & 10 & 8 & 3 & 6 & 3 & 1 & 18 & 31 & 11 & 1 & 6 & 3 \\
\hline NHAF & 912 & 41000 & 1810 & 7187 & 1530 & 1716 & 583 & 1419 & 488 & 301 & 4687 & 7070 & 2746 & 261 & 1276 & 723 \\
\hline SHAF & 1437 & 66818 & 3030 & 11118 & 2540 & 2635 & 900 & 2184 & 828 & 507 & 7846 & 11742 & 4739 & 423 & 1747 & 1140 \\
\hline AUSTR & 74 & 3399 & 151 & 648 & 128 & 136 & 46 & 122 & 40 & 24 & 377 & 566 & 216 & 21 & 166 & 54 \\
\hline EQAS & 437 & 23706 & 1270 & 5981 & 521 & 699 & 241 & 930 & 207 & 124 & 2495 & 3395 & 1234 & 135 & 78 & 353 \\
\hline SEAS & 1631 & 86666 & 4418 & 19607 & 2778 & 2723 & 960 & 3040 & 978 & 546 & 9441 & 13576 & 5300 & 514 & 397 & 1307 \\
\hline CENAS & 136 & 7969 & 382 & 2815 & 477 & 248 & 102 & 283 & 142 & 47 & 623 & 1099 & 379 & 48 & 54 & 85 \\
\hline BORAS & 382 & 22761 & 1079 & 6064 & 1259 & 679 & 286 & 701 & 467 & 169 & 2222 & 3511 & 1399 & 112 & 97 & 238 \\
\hline
\end{tabular}

Table 9. Comparison of FINNv1 and the annual output from GFEDv3.1. The values here represent the ratio of the annual average FINNv1 emissions to the GFEDv3.1 emissions.

\begin{tabular}{cccccccccc}
\hline & $\mathrm{CO}_{2}$ & $\mathrm{CO}$ & $\mathrm{CH}_{4}$ & $\mathrm{NMHC}$ & NMOC* $^{*}$ & $\mathrm{NO}$ & $\mathrm{SO}_{2}$ & $\mathrm{BC}$ & $\mathrm{OC}$ \\
\hline 2005 & 1.07 & 1.07 & 0.98 & 0.59 & 3.8 & 1.30 & 1.04 & 1.03 & 1.26 \\
2006 & 1.12 & 1.06 & 0.89 & 0.61 & 4.3 & 1.30 & 1.05 & 1.09 & 1.30 \\
2007 & 1.05 & 1.10 & 1.04 & 0.59 & 3.8 & 1.27 & 1.05 & 1.02 & 1.27 \\
2008 & 1.14 & 1.20 & 1.17 & 0.73 & 4.2 & 1.35 & 1.18 & 1.10 & 1.33 \\
2009 & 1.34 & 1.38 & 1.28 & 0.80 & 5.0 & 1.61 & 1.37 & 1.32 & 1.61 \\
\hline
\end{tabular}

* This represents the ratio of NMOC from FINNv1 divided by the NMHC emissions of GFEDv3.1.

\subsection{High variability and major features of emission rates}

The daily emissions of total identified NMOC for the Northern Hemisphere, the Southern Hemisphere, and the globe are shown in Fig. 5. The interannual variability can be quite substantial, particularly at the hemispheric and regional scales. Weekly and daily emissions for specific time periods can vary by more than a factor of two from year to year. The NMOC emissions (as well as the other emissions of other species not shown) are also extremely variable day to day confirming the need for high temporal resolution for some applications.

The major temporal features of the FINNv1 emissions are summarized next. Two general peaks in emissions occur each year. The first peak is from $\sim$ mid-February through May and is primarily caused by the burning in the tropical and subtropical regions of the Northern Hemisphere. A second peak occurs from August through September, which corresponds to burning in the Southern Hemisphere tropics. Assuming that $\mathrm{CO}_{2}$ and NMOC are emitted proportionally from open biomass burning, this second peak in emissions is qualitatively similar to what is presented for open burn- ing $\mathrm{CO}_{2}$ emissions estimated by the GICC. However, the first peak in FINNv1 NMOC emissions is somewhat different from the GICC CO 2 estimates for 1997-2005, which show a peak in the global $\mathrm{CO}_{2}$ emissions starting in January of each year (Fig. 4 of Mieville et al., 2010).

Regionally, emissions from open biomass burning show substantial variability. Figure 6 shows the spatial distribution of $\mathrm{CO}$ emissions from FINNv1 (allocated to a $1^{\circ} \times 1^{\circ}$ resolution) for four months (January, April, July, and October) in 2008. FINNv1 emissions for January are relatively low and are centered near the equator. $\mathrm{CO}$ emissions in the tropical Northern Hemisphere, specifically Southeast Asia and Central America, are high during the spring months. There are also large emissions associated with burning throughout Central Asia. SH emissions predicted for July are located mainly in South America and Africa, while NH July emissions are found mainly in North America, and Northern Asia. In October, open burning emissions are mostly produced in the Southern Hemisphere (Figs. 5 and 6). 
Table 10. Global emissions $\left(\mathrm{Tg} \mathrm{yr}^{-1}\right)$ for selected species of the MOZART-4 chemical mechanism.

\begin{tabular}{cccccccccc}
\hline Year & HCHO & ISOPRENE & $\mathrm{HCN}$ & $\mathrm{CH}_{3} \mathrm{CN}$ & $\mathrm{CH}_{3} \mathrm{OH}$ & $\mathrm{HCOOH}$ & $\mathrm{C}_{2} \mathrm{H}_{6}$ & $\mathrm{C}_{2} \mathrm{H}_{4}$ & $\mathrm{C}_{2} \mathrm{H}_{2}$ \\
\hline 2005 & 5.2 & 0.8 & 1.5 & 1.3 & 6.6 & 2.0 & 2.0 & 3.4 & 0.8 \\
2006 & 5.8 & 0.9 & 1.7 & 1.4 & 7.5 & 2.2 & 2.3 & 3.8 & 0.9 \\
2007 & 5.0 & 0.7 & 1.4 & 1.2 & 6.4 & 1.9 & 1.9 & 3.3 & 0.8 \\
2008 & 4.3 & 0.8 & 1.4 & 1.1 & 5.5 & 1.8 & 1.7 & 2.9 & 0.7 \\
2009 & 4.7 & 0.7 & 1.4 & 1.1 & 6.0 & 1.8 & 1.8 & 3.1 & 0.7 \\
2010 & 5.5 & 0.8 & 1.6 & 1.3 & 7.1 & 2.0 & 2.2 & 3.6 & 0.8 \\
\hline
\end{tabular}
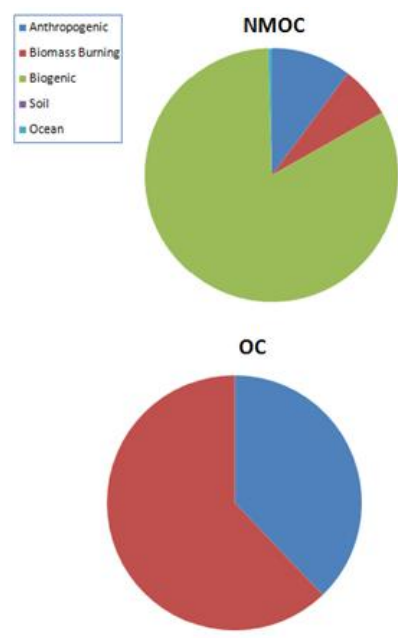

co

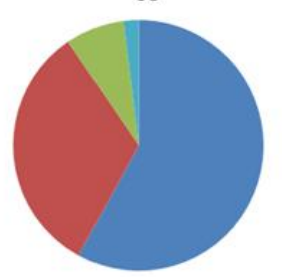

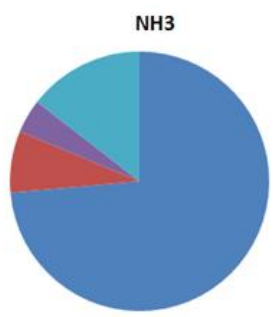

$\mathrm{BC}$

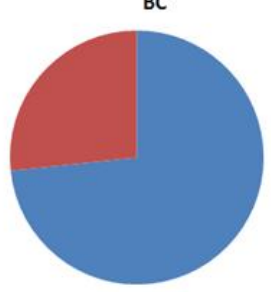

NO+NO2

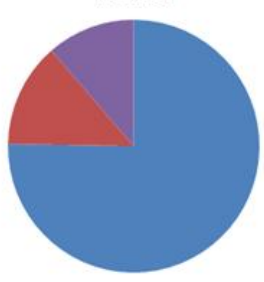

Fig. 4. Distribution of global emissions by source from FINNv1 (for 2008; labeled as Biomass Burning) and the emission inventories applied by MOZART-4 (Emmons et al., 2010a). Anthropogenic emissions include biofuel use.

\subsection{Applications}

The FINNv1 model was created to provide near real-time estimates of open burning emissions that can easily be incorporated into chemical transport models. FINNv1 emissions or their predecessors have already been used successfully in several regional and global applications (e.g., Fast et al., 2009; Emmons et al., 2010b; Pfister et al., 2008; Hodzic et al., 2007). Methods for allocating the emissions to a diurnal cycle and incorporating plume rise can be found elsewhere (e.g., Freitas et al., 2009; WRAP 2005). Because the FINNv1 emissions can be produced within a few hours of

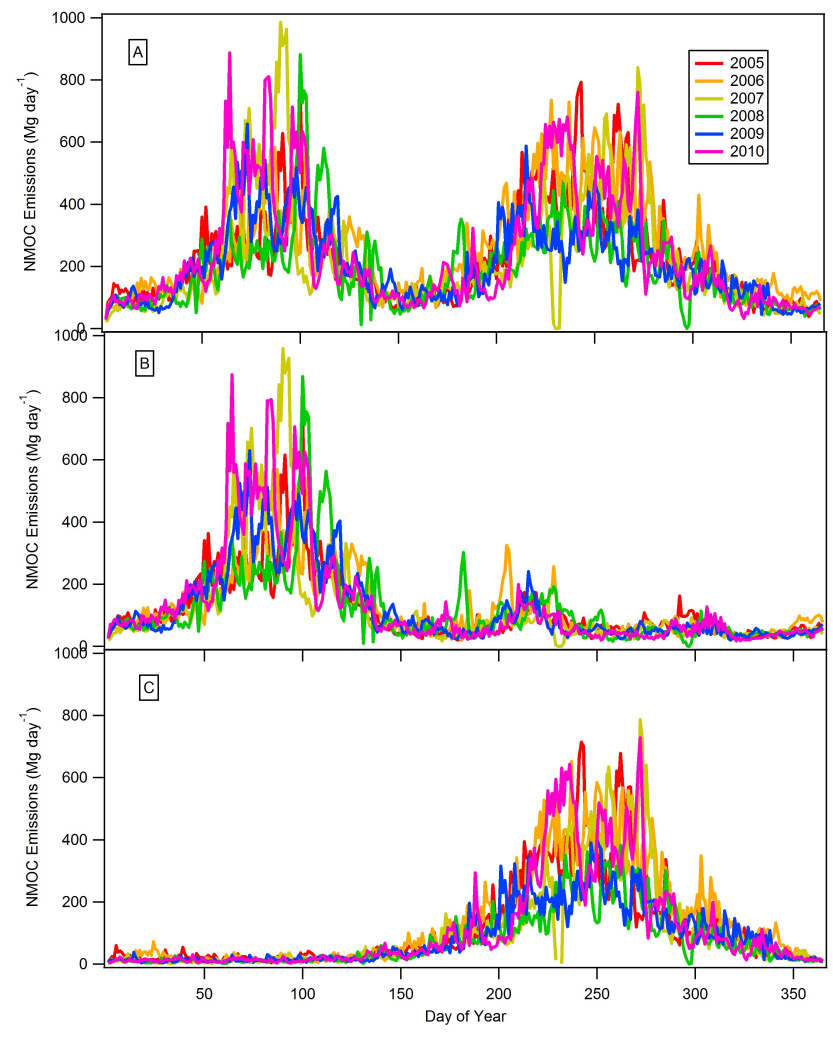

Fig. 5. Daily emissions of NMOC from fires for 2005 through 2010 for (A) the globe, (B) the Northern Hemisphere, and (C) the Southern Hemisphere.

each satellite overpass, they can be used for model forecast applications. FINNv1 emissions can be generated interactively and feedback provided by users will improve future versions of the model. The FINNv1 emission estimates have advantages over some other inventories when high spatial and/or temporal resolution or rapid availability is needed. For example, despite the limitations of using the daily fire counts (see Sect. 3.5), the daily estimates allow models to capture the highly episodic nature of fire emissions that could be missed with smoothing to 8-day resolution or using monthly fire counts, as is commonly done. Additionally, 

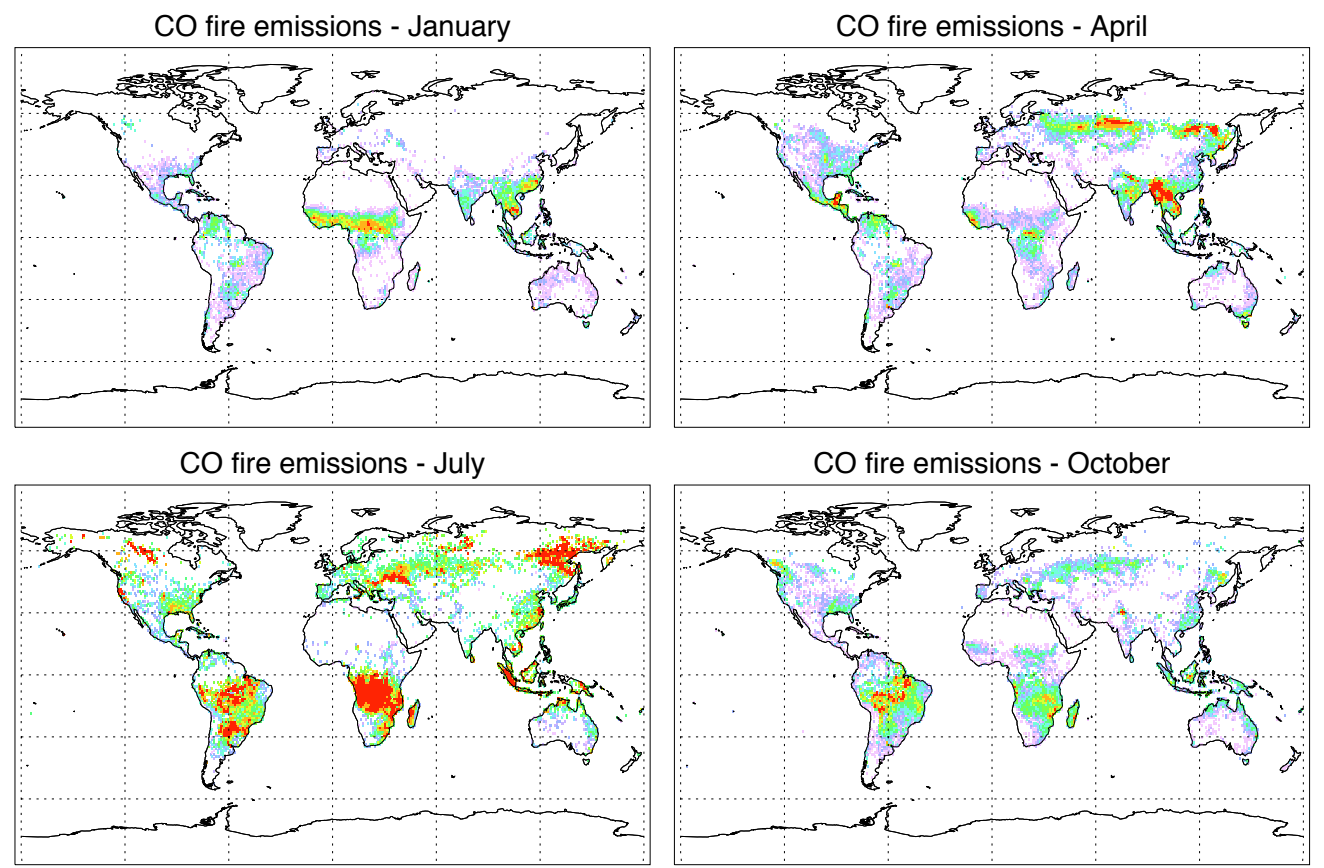

molecules/cm2/s

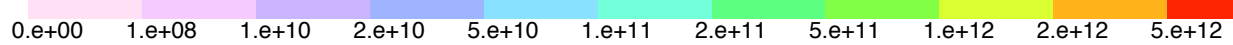

Fig. 6. Monthly CO emissions from FINNv1, gridded to $1^{\circ} \times 1^{\circ}$ for January, April, July and October 2008 .

FINNv1 produces consistent emission estimates from coarse grid scales to local scales, which facilitates comparisons and is useful for nested applications.

\section{Limitations and uncertainties}

FINNv1 produces high-resolution (spatial and temporal) emissions from open biomass burning on a global scale relatively quickly (on the order of minutes to hours). Although useful for multiple applications, the estimates are very uncertain and have only begun to be compared to observations (e.g., Pfister et al., 2011). Uncertainties associated with many aspects of the estimation process are described in detail by Wiedinmyer et al. (2006) and below. In summary, since most global fires are "small" it is likely that the largest uncertainties arise from (1) missed fires causing an underestimation of the number of fires and (2) overestimating the size of the small fires that are detected. These errors tend to cancel as discussed by Wiedinmyer et al. (2006) and Yokelson et al. (2009); however, this can be regionally dependent. Additional uncertainty could arise from misidentification of the land cover, inaccurate fuel loading and parameterizations of combustion completeness, and both uncertainty and natural variation in the emission factors (Akagi et al., 2011). Other assumptions made in FINNv1 also add uncertainty, such as the smoothing of the fire detections in tropical latitudes to account for the lack of daily coverage by the MODIS instruments in this region, and the assumed burned area of each fire. For the global application described here, average values for variable phenomena are applied to broad regions. The average value may not always represent the real value for some fires or some years. Next we discuss three of the sources of uncertainty in more detail.

Satellite overpass timing and cloud cover may prevent the detection of fires. The need to estimate the number of fires on days without coverage limits the accuracy of any emissions model. Additionally, all remote sensing thermal anomaly products do not detect most of the fires less than $\sim 100$ ha and some understory fires (e.g. Hawbaker et al., 2008), both of which can be a significant source of emissions to the atmosphere.

The assumed burned area estimated by the FINN methods is highly uncertain. As a simple first approach, a maximum burn area is assumed for each fire pixel detected. The resulting global burned area estimates from FINNv1 are higher than other global estimates. For example, Tansey et al. (2008b) estimate that the annual average global burned area from 2000-2006 was $3.9 \mathrm{Mkm}^{2}$, whereas the annual average (2005-2010) from FINNv1 is $4.8 \mathrm{Mkm}^{2}$. The different burned area estimates of FINNv1 compared to other estimates highlight the uncertainty and variability in this component of the emissions model; however, we believe that the estimates are within the overall uncertainty associated with burned area estimates. For example, Burling et al. (2011) 
sampled 14 prescribed fires carried out by government agencies in the US ranging from seven to over 1000 ha in 2009 2010. None of these fires were detected in the standard MODIS burned area product, and five of the 14 were detected as hot spots. The actual total area burned by these fires was 1843 ha. The FINNv1 burned area estimate for these fires would be $\sim 500$ ha, and the MODIS burned area for these fires would be zero ha. Both products seemingly underestimated these fires, which were mostly small. In southern Mexico in 2006, Yokelson et al. (2011) sampled 56 fires. Ten of these fires registered as MODIS hotspots, and MODIS burned area information is not reported for these fires. A ground-based crew measured the size of six of the Mexican fires (Yokelson et al., 2007). The total area burned in these six fires was 368 ha. One of these six fires generated a hotspot, so the FINNv1 burned area for these fires is $\sim 100$ ha. Again, small fires tend to be underestimated. Coincidentally, the FINNv1 burned area estimate was an identical $27 \%$ of actual for both US prescribed fires and fires in the Mexican tropics.

The relationship between fire detections and area burned is highly uncertain and the topic of much on-going research. For example, Tansey et al. (2008a) provide relationships between fire hot spots and burn area for tropical peat forests in Indonesia. To reduce the uncertainties due to the burn area estimates within FINN, we will look to incorporate any robust relationships between hot spots and burned area in future versions.

The land use/land cover (LULC) classifications assigned to the fires introduces some uncertainty to the emission estimates. For the results presented here, the satellite-derived MODIS LCT and VCF products are used to identify the type and density of vegetation burned. These products were chosen specifically because of their consistency with the MODIS fire detections, easy access, and easy use. Yet, determination of ecosystem type can vary significantly from one land cover data product to another. For example, Wiedinmyer et al. (2006) showed that the use of three different LULC datasets to drive a regional fire emissions model for North and Central America led to $26 \%$ differences in annual emission estimates. Those authors ultimately selected the Global Land Cover 2000 product (GLC2000; Fritz et al., 2003) to determine the land cover burned at each fire in North and Central America (Wiedinmyer et al., 2006). Giri et al. (2005) detail differences in the MODIS LCT product and the GLC2000 dataset and show that the area totals of the generic land covers agree reasonable well globally, except for woody savannas/shrublands and wetlands. However, at the pixel level, agreement between the two datasets is not as good. A fire located in a forest will typically be associated with more emissions than a fire located in grasslands due to the higher fuel loadings. Thus, the determination of land cover and vegetation coverage can introduce significant error in the emission estimates.
Correct assignment of the vegetation does not prevent uncertainty due to the fuel consumption estimates. Only one value for fuel loading is assigned to each land cover type in each region. A constant value is most likely not representative of a vegetation class within an entire region and will not reproduce the full heterogeneity of the landscapes. For example, Soja et al. (2004) found that disparities in the amount of carbon stored in unique Siberian ecosystems and the severity of fire events can affect total direct carbon emissions by as much as $50 \%$. However, a strength of FINNv1 is that it is relatively easy to introduce specific regional information to replace the generic information in an effort to reduce uncertainties in the emission estimation process. For example, as discussed above, specific fuel loadings for crop fires in a small area of Brazil were applied to account for sugar cane burning.

The uncertainty in total emissions that can arise from coupling all the inherent uncertainties is illustrated briefly with a few examples. Al-Saadi et al. (2008) reported that monthly fire emission estimates generated for the contiguous US over several months in 2006 by various remote sensingbased techniques varied by an order of magnitude. Roy and Boschettio (2009) evaluated three remotely-sensed burned area products (L3JRC, GlobCarbon, and MODIS) for the burning season in Southern Africa using the Landsat Enhanced Thematic Mapper Plus data for the evaluation dataset. They found that the MODIS burned area product was the most accurate for that region and highlight the variability in the various products. The use of various burned area products can lead to increased uncertainty in the emission estimates produced. Chang and Song (2010) used two different burned area products to derive their open burning emissions for Southeast Asia: the L3JRC and the Collection 5 MODIS (MCD45A1) burned-area products. They found that the average annual burned area estimates for the two products over Asia from 2000-2006 were almost a factor of 2 different, and the interannual variation in the burned area estimates differed as well. When compared to the annual average burned area estimates of GFEDv2 for the same time period, GFEDv2 was $50 \%$ greater than the MCD45A1 burned area estimates and almost a factor of 2 higher than the L3JRC estimates.

In light of the above discussion, we examine some of the sources of uncertainty in FINNv1 in more detail. To test the sensitivity of the emissions to the input land cover, we used the GLOBCOVER global vegetation map (downloaded from http://ionia1.esrin.esa.int/index.asp, January 2010), to assign land cover for detected fires in FINNv1. Globally, the annual (2006) total emissions of CO did not change significantly ( $2 \%$ ) between the default case and the GLOBCOVER run, although emissions of $\mathrm{NO}_{\mathrm{x}}$ and $\mathrm{NH}_{3}$ change by as much as $24 \%$. However, the amount of some landcover types that is assumed to burn globally in each run changes substantially when the different land cover datasets are applied, which can have large impacts on the estimated emissions from a region since different land covers have varying emission factors and 
fuel loadings that can lead to variations in emission estimates. For example, globally for 2006, the GLOBCOVER simulation estimates that more than 3 times the amount of temperate forest burns compared to the default run driven by the MODIS LCT data. Additionally, the LCT data implies that more shrubland and grasslands burn globally. Regional variation is also high. For example, the GLOBCOVER assigned $70 \%$ more forest fires to the contiguous U.S., Mexico, and Central America, leading to $20 \%$ higher CO and $24 \%$ higher NMOC emissions than the default simulation in these regions. In this case, the MODIS LCT assigned more shrubland, cropland and grassland fires. The total emissions estimated using GLOBCOVER were only $10 \%$ lower in Canada and Alaska than the default simulation, due to fewer forest fires assigned in these areas.

In summary, a quantitative assignment of uncertainty is difficult, due to the uncertainties associated with the land cover classifications, the fire detections, the assumed area burned, the biomass loading, the amount of fuel burned, and emission factors. van der Werf et al. (2010) provide the results of extensive Monte Carlo simulations for the GFEDv3.1 model and show uncertainties in the global carbon emissions greater than a factor of two for some years. Further, they note that regional and seasonal uncertainties are larger on regional and monthly scales. At this time, we follow other efforts (e.g., Wiedinmyer et al., 2006; Mieville et al., 2010) and assign the uncertainty as approximately a factor of two for the FINNv1 estimates. We will continue to apply in situ measurements, satellite observations, and model simulations to evaluate the accuracy of the estimates provided here. Future versions of FINN will contain updates intended to reduce these uncertainties.

\section{Conclusions}

Open biomass burning injects significant amounts of particulate matter and trace gases into the atmosphere. The Fire INventory from NCAR version 1.0 (FINNv1) estimates these emissions daily on a global basis at a resolution of $1 \mathrm{~km}^{2}$. The inclusion of a number of important individual trace gases and particulate species is presented. FINNv1 also provides speciation profiles for several lumped chemical mechanisms used by some chemical transport models. FINNv1 includes updated emission factors for non-methane organic compounds, which may have an important impact on the way in which global and regional chemistry is simulated. Strengths of FINNv1 include: it quickly provides modelers with reasonable, high temporal/spatial resolution fire emission estimates based on updated emission factors, and it is easily adapted to more accurately target specific regions of interest.

For many chemical species, the FINNv1 emission estimates agree well with other inventories; specifically the GICC and the GFEDv3. However, this does not in itself establish the absolute accuracy of the estimates because open burning emission estimates are subject to inherent limitations that lead to large uncertainties. These uncertainties are associated with the input data used for fire identification and land cover classifications, assumptions used to estimate burned area, fuel loading and consumption, and estimates of the amount and types of emissions from the identified fires. Thus, the uncertainty assigned to the FINNv1 estimates is about a factor of 2. Future work will compare the FINNv1 estimates to in situ measurements, satellite observations, and chemical transport models. Incorporation of more robust relationships between rapid fire detections and actual burned area could be included to better simulate burned area in the model framework.

Acknowledgements. The National Center for Atmospheric Research is operated by the University Corporation for Atmospheric Research under sponsorship of the National Science Foundation. The authors greatly thank Minnie Wong of the University of Maryland for the distribution of the MODIS fire count data. CW thanks Matthew Evans for assistance with the GEOS-Chem mechanism. The authors would also like to thank the two anonymous reviewers of this manuscript for their valuable comments.

Edited by: V. Grewe

\section{References}

Akagi, S. K., Yokelson, R. J., Wiedinmyer, C., Alvarado, M. J., Reid, J. S., Karl, T., Crounse, J. D., and Wennberg, P. O.: Emission factors for open and domestic biomass burning for use in atmospheric models, Atmos. Chem. Phys., 11, 4039-4072, doi:10.5194/acp-11-4039-2011, 2011.

Al-Saadi, J., Soja, A., Pierce, R. B., Szykman, J., Wiedinmyer, C., Emmons, L., Kondragunta, S., Zhang, X., Kittaka, C., Schaack, T., and Bowman, K.: Evaluation of near-real-time biomass burning emissions estimates constrained by satellite fire data, J. Appl. Remote Sens., 2, 021504, doi:10.1117/1.2948785, 2008.

Andreae, M. O. and Merlet, P.: Emission of trace gases and aerosols from biomass burning, Global Biogeochem. Cy., 15(4), 955-966, 2001.

Andreae, M. O. and Rosenfeld, D.: Aerosol-cloudprecipitation interactions. Part 1 , The nature and sources of cloud-active aerosols, Earth Sci. Rev., 89, 13-41. doi:10.1016/j.earscirev.2008.03.001, 2008.

Arellano, A. F., Kasibhatla, P. S., Giglio, L., van der Werf, G. R., and Randerson, J. T.: Top-down estimates of global CO sources using MOPITT measurements, Geophys. Res. Lett., 31, L01104, doi:10.1029/2003GL018609, 2004.

Arellano Jr., A. F., Kasibhatla, P. S., Giglio, L., van der Werf, G. R., Randerson, J. T., and Collatz, G. J.: Time- dependent inversion estimates of global biomass-burning $\mathrm{CO}$ emissions using Measurement of Pollution in the Troposphere (MOPITT) measurements, J. Geophys. Res., 111, D09303, doi:10.1029/2005JD006613, 2006.

Bey, I., Jacob, D. J., Yantosca, R. M., Logan, J. A., Field, B., Fiore, A. M., Li, Q., Liu, H., Mickley, L. J., and Schultz, M.: Global modeling of tropospheric chemistry with assimilated meteorol- 
ogy: Model description and evaluation, J. Geophys. Res., 106, 23073-23096, 2001.

Bond, T. C., Streets, D. G., Yarber, K. F., Nelson, S. M., Woo, J.H., and Klimont, Z.: A technology-based global inventory of black and organic carbon emissions from combustion, J. Geophys. Res., 109, D14203, doi:10.1029/2003JD003697, 2004.

Burling, I. R., Yokelson, R. J., Akagi, S. K., Urbanski, S. P., Wold, C. E., Griffith, D. W. T., Johnson, T. J., Reardon, J., and Weise, D. R.: Airborne and ground-based measurements of the trace gases and particles emitted by prescribed fires in the United States, Atmos. Chem. Phys. Discuss., 11, 18677-18727, doi:10.5194/acpd-11-18677-2011, 2011.

Campbell, J., Donato, D., Azuma, D., and Law, B.: Pyrogenic carbon emission from a large wildfire in Oregon, United States, J. Geophys. Res., 112, G04014, doi:10.1029/2007JG000451, 2007.

Carroll, M., Townshend, J., Hansen, M., DiMiceli, C., Sohlberg, R., and Wurster, K.: Vegetative Cover Conversion and Vegetation Continuous Fields, in: Land Remote Sensing and Global Environmental Change: NASA's Earth Observing System and the Science of Aster and MODIS, edited by: Ramachandran, B., Justice, C. O., and Abrams, M., Springer-Verlag, 11, 725-746, doi:10.1007/978-1-4419-6749-7, 2011.

Carter, W. P. L.: Implementation of the SAPRC-99 chemical mechanism into the Models-3 framework, US EPA, 2000.

Chang, D. and Song, Y.: Estimates of biomass burning emissions in tropical Asia based on satellite-derived data, Atmos. Chem. Phys., 10, 2335-2351, doi:10.5194/acp-10-2335-2010, 2010.

Christian, T. J., Kleiss, B., Yokelson, R. J., Holzinger, R., Crutzen, P. J., Hao, W. M., Saharjo, B. H., and Ward, D. E.: Comprehensive laboratory measurements of biomass-burning emissions, 1. Emissions from Indonesian, African, and other fuels, J. Geophys. Res., 108, 4719, doi:10.1029/2003JD003704, 2003.

Colarco, P., da Silva, A., Chin, M., and Diehl, T.: Online simulations of global aerosol distributions in the NASA GEOS-4 model and comparisons to satellite and groundbased aerosol optical depth, J. Geophys. Res., 115, D14207, doi:10.1029/2009JD012820, 2010.

Crutzen, P. J. and Andeae, M. O.: Biomass burning in the tropicsimpact on atmospheric chemistry and biogeochemical cycles, Science, 250(4988), 1669-1678, 1990.

Davies, D. K., Ilavajhala, S., Wong, M. M., and Justice, C. O.: Fire Information for Resource Management System: Archiving and Distributing MODIS Active Fire Data, IEEE T. Geosci. Remote Sens., 47(1), 72-79, 2009.

Duncan, B. N., Martin, R. V., Staudt, A. C., Yevich, R., and Logan, J. A.: Interannual and seasonal variability of biomass burning emissions constrained by satellite observations, J. Geophys. Res., 108(D2), 4100, doi:10.1029/2002JD002378, 2003.

Friedl, M. A., Sulla-Menashe, D., Tan, B., Schneider, A., Ramankutty, N., Sibley, A., and Huang, X.: MODIS collection 5 global land cover: algorithm refinements and characterization of new datasets, Remote Sens. Environ., 114(1), 168-182, 2010.

Emmons, L. K., Walters, S., Hess, P. G., Lamarque, J.-F., Pfister, G. G., Fillmore, D., Granier, C., Guenther, A., Kinnison, D., Laepple, T., Orlando, J. J., Tie, X., Tyndall, G., Wiedinmyer, C., Baughcum, S. L., and Kloster, S.: Description and evaluation of the Model for Ozone and Related chemical Tracers, version 4 (MOZART-4), Geosci. Model Dev., 3, 43-67, doi:10.5194/gmd3-43-2010, 2010a.
Emmons, L. K., Apel, E. C., Lamarque, J.-F., Hess, P. G., Avery, M., Blake, D., Brune, W., Campos, T., Crawford, J., DeCarlo, P. F., Hall, S., Heikes, B., Holloway, J., Jimenez, J. L., Knapp, D. J., Kok, G., Mena-Carrasco, M., Olson, J., O’Sullivan, D., Sachse, G., Walega, J., Weibring, P., Weinheimer, A., and Wiedinmyer, C.: Impact of Mexico City emissions on regional air quality from MOZART-4 simulations, Atmos. Chem. Phys., 10, 6195-6212, doi:10.5194/acp-10-6195-2010, 2010b.

Fast, J., Aiken, A. C., Allan, J., Alexander, L., Campos, T., Canagaratna, M. R., Chapman, E., DeCarlo, P. F., de Foy, B., Gaffney, J., de Gouw, J., Doran, J. C., Emmons, L. K., Hodzic, A., Herndon, S. C., Huey, G., Jayne, J. T., Jimenez, J. L., Kleinman, L., Kuster, W., Marley, N., Russell, L., Ochoa, C., Onasch, T. B., Pekour, M., Song, C., Ulbrich, I. M., Warneke, C., WelshBon, D., Wiedinmyer, C., Worsnop, D. R., Yu, X.-Y., and Zaveri, R.: Evaluating simulated primary anthropogenic and biomass burning organic aerosols during MILAGRO: implications for assessing treatments of secondary organic aerosols, Atmos. Chem. Phys., 9, 6191-6215, doi:10.5194/acp-9-6191-2009, 2009.

Freitas, S. R., Longo, K. M., Silva Dias, M. A. F., Chatfield, R., Silva Dias, P., Artaxo, P., Andreae, M. O., Grell, G., Rodrigues, L. F., Fazenda, A., and Panetta, J.: The Coupled Aerosol and Tracer Transport model to the Brazilian developments on the Regional Atmospheric Modeling System (CATT-BRAMS) - Part 1: Model description and evaluation, Atmos. Chem. Phys., 9, 28432861, doi:10.5194/acp-9-2843-2009, 2009.

Fritz, S., Bartholomé, E., Belward, A., Hartley, A., Stibig, H.-J., Eva, H., Mayaux, P., Bartalev, S., Latifovic, R., Kolmert, S., Roy, P., Agrawal, S., Bingfang,W., Wenting, X., Ledwith, M., Pekel, F. J., Giri, C., Mücher, S., Badts, E., Tateishi, R., Champeaux, J.L., and Defourny, P.: Harmonization, mosaicing, and production of the Global Land Cover 2000 database (Beta Version), Ispra, Italy Joint Research Center (JRC), 2003.

Giglio, L., Csiszar, I., and Justice, C. O.: Global distribution and seasonality of active fires as observed with the Terra and Aqua Moderate Resolution Imaging Spectroradiometer (MODIS) sensors, J. Geophys. Res., 111, G02016, doi:10.1029/2005JG000142, 2006.

Giglio, L., Randerson, J. T., van der Werf, G. R., Kasibhatla, P. S., Collatz, G. J., Morton, D. C., and DeFries, R. S.: Assessing variability and long-term trends in burned area by merging multiple satellite fire products, Biogeosciences, 7, 1171-1186, doi:10.5194/bg-7-1171-2010, 2010.

Giri, C., Zhu, Z., and Reed, B.: A comparative analysis of the Global Land Cover 2000 and MODIS land cover data sets, Remote Sens. Environ., 94, 123-132, 2005.

Guenther, A., Karl, T., Harley, P., Wiedinmyer, C., Palmer, P. I., and Geron, C.: Estimates of global terrestrial isoprene emissions using MEGAN (Model of Emissions of Gases and Aerosols from Nature), Atmos. Chem. Phys., 6, 3181-3210, doi:10.5194/acp-63181-2006, 2006.

Hansen, M. C., DeFries, R. S., Townshend, J. R. G., Carroll, M., DiMiceli, C., and Sohlberg, R.: Global percent tree cover at a spatial resolution of 500 meters: first results of the MODIS Vegetation Continuous Fields algorithm, Earth Interact., 7, 1-15, 2003.

Hansen, M. C., Townshend, J. R. G., DeFries, R. S., and Carroll, M.: Estimation of tree cover using MODIS data at global, continental and regional/local scales, Int. J. Remote Sens., 26, 4359-4380, 
2005.

Hawbaker, T. J., Radeloff, V. C., Syphard, A. D., Zhu, Z. L., and Steward, S. I.: Detection rates of the MODIS active fire product in the United States. Remote Sens. Environ., 112(5) 2656-2664, 2008.

Hodzic, A., Madronich, S., Bohn, B., Massie, S., Menut, L., and Wiedinmyer, C.: Wildfire particulate matter in Europe during summer 2003: meso-scale modeling of smoke emissions, transport and radiative effects, Atmos. Chem. Phys., 7, 4043-4064, doi:10.5194/acp-7-4043-2007, 2007.

Hoelzemann, J. J., Schultz, M. G., Brasseur, G. P., Granier, C., and Simon, M.: Global Wildland Fire Emission Model (GWEM): Evaluating the use of global area burnt satellite data, J. Geophys. Res., 109, D14S04, doi:10.1029/2003JD003666, 2004.

Holzinger, R., Warneke, C., Hansel, A., Jordan, A., Lindinger, W., Scharffe, D. H., Schade, G., and Crutzen, P. J.: Biomass burning as a source of formaldehyde, acetaldehyde, methanol, acetone, acetonitrile, and hydrogen cyanide, Geophys. Res. Lett., 26(8), 1161-1164, 1999.

IPCC: Contribution of Working Group I to the Fourth Assessment Report of the Intergovernmental Panel on Climate Change, edited by: Solomon, S., Qin, D., Manning, M., Chen, Z., Marquis, M., Averyt, K. B., Tignor, M., and Miller, H. L. Cambridge University Press, Cambridge, United Kingdom and New York, NY, USA, 2007.

Ito, A. and Penner, J. E.: Global estimates of biomass burning emissions based on satellite imagery for the year 2000, J. Geophys. Res., 109, D14S05, doi:10.1029/2003JD004423, 2004.

Karl, T., Guenther, A., Yokelson, R. J., Greenberg, J., Potosnak, M., Blake, D. R., and Artaxo, P.: The tropical forest and fire emissions experiment: Emission, chemistry, and transport of biogenic volatile organic compounds in the lower atmosphere over Amazonia, J. Geophys. Res., 112, D18302, doi:10.1029/2007JD008539, 2007.

Kopacz, M., Jacob, D. J., Fisher, J. A., Logan, J. A., Zhang, L., Megretskaia, I. A., Yantosca, R. M., Singh, K., Henze, D. K., Burrows, J. P., Buchwitz, M., Khlystova, I., McMillan, W. W., Gille, J. C., Edwards, D. P., Eldering, A., Thouret, V., and Nedelec, P.: Global estimates of $\mathrm{CO}$ sources with high resolution by adjoint inversion of multiple satellite datasets (MOPITT, AIRS, SCIAMACHY, TES), Atmos. Chem. Phys., 10, 855-876, doi:10.5194/acp-10-855-2010, 2010.

Larkin, N. K., O’Neill, S. M., Solomon, R., Raffuse, S., Strand, T., Sullivan, D. C., Krull, C., Rorig, M., Peterson, J. L., and Ferguson, S. A.: The BlueSky smoke modeling framework, Int. J. Wildland Fire, 18(8), 906-920, 2009.

Lavoue, D., Liousse, C., Cachier, H., Stocks, B. J., and Goldammer, J. G.: Modeling of carbonaceous particles emitted by boreal and temperate wildfires at northern latitudes, J. Geophys. Res., 105(D22), 26871-26890, 2000.

Lobert, J. M., Keene, W. C., Logan, J. A., and Yevich, R.: Global chlorine emissions from biomass burning: reactive chlorine emissions inventory, J. Geophys. Res.-Atmos., 104(D7), 83738389, 1999.

Macedo, I. C., Seabra, J. E. A., and Silva, J.: Green house gases emissions in the production and use of ethanol from sugarcane in Brazil: The 2005/2006 averages and a prediction for 2020, Biomass Bioenerg., 32(7), 582-595, 2008.

Magi, B. I., Ginoux, P., Ming, Y., and Ramaswamy, V.: Evalua- tion of tropical and extratropical Southern Hemisphere African aerosol properties simulated by a climate model, J. Geophys. Res., 114, D14204, doi:10.1029/2008JD011128, 2009.

McMeeking, G. R.: The optical, chemical, and physical properties of aerosols and gases emitted by the laboratory combustion of wildland fuels, Ph.D. Dissertation, Department of Atmospheric Sciences, Colorado State University, 109-113, Fall 2008.

McMeeking, G. R., Kreidenweis, S. M., Lunden, M., Carrillo, J., Carrico, C. M., Lee, T., Herckes, P., Engling, G., Day, D. E., Hand, J., Brown, N., Malm, W. C., and Collett, J. L.: Smokeimpacted regional haze in California during the summer of 2002, Agr. Forest Meteorol., 137(1-2), 25-42, 2006.

Michel, C. , Liousse, C., Grgoire, J.-M., Tansey, K., Carmichael, G. R., and Woo, J.-H.: Biomass burning emission inventory from burnt area data given by the SPOT-VEGETATION system in the frame of TRACE-P and ACE-Asia campaigns, J. Geophys. Res., 110, D09304, doi:10.1029/2004JD005461, 2005.

Mieville, A., Granier, C., Liousse, C., Guillaume, B., Mouillot, F., Lamarque, J.-F., Gregoire, J.-M., Petron, G.: Emissions of gases and particles from biomass burning during the 20th century using satellite data and an historical reconstruction, Atmos. Environ., 44, 1469-1477, 2010.

Muhle, J., Lueker, T. J., Su, Y., Miller, B. R., Prather, K. A., and Weiss, R. F.: Trace gas and particulate emissions from the 2003 southern California wildfires, J. Geophys. Res., 112, D03307, doi:10.1029/2006JD007350, 2007.

NASA/University of Maryland, MODIS Hotspot/Active Fire Detections, Data set, MODIS Rapid Response Project, NASA/GSFC (producer), University of Maryland, Fire Information for Resource Management System (distributors), available at: http: //maps.geog.umd.edu (last access: 3 May 2011), 2002.

Nassar, R., Logan, J. A., Megretskaia, I. A., Murray, L. T., Zhang, L., and Jones, D. B. A.: Analysis of tropical tropospheric ozone, carbon monoxide, and water vapor during the $2006 \mathrm{El} \mathrm{Ni}$ ño using TES observations and the GEOS-Chem model, J. Geophys. Res., 114, D17304, doi:10.1029/2009JD011760, 2009.

Olivier, J. G. J., van Aardenne, J. A., Dentener, F., Pagliari, V., Ganzeveld, L. N., and Peters, J. A. H. W.: Recent trends in global greenhouse gas emissions: regional trends 1970-2000 and spatial distribution of key sources in 2000, Environ. Sci., 2 (2-3), 81-99, doi:10.1080/15693430500400345, 2005.

Pfister, G. G., Wiedinmyer, C., and Emmons, L. K.: Impacts of the fall 2007 California wildfires on surface ozone: Integrating local observations with global model simulations, Geophys. Res. Lett., 35(19), doi:10.1029/2008GL034747, 2008.

Pfister, G. G., Parrish, D. D., Worden, H., Emmons, L. K., Edwards, D. P., Wiedinmyer, C., Diskin, G. S., Huey, G., Oltmans, S. J., Thouret, V., Weinheimer, A., and Wisthaler, A.: Characterizing summertime chemical boundary conditions for airmasses entering the US West Coast, Atmos. Chem. Phys., 11, 1769-1790, doi:10.5194/acp-11-1769-2011, 2011.

Pope, C. A. and Dockery, D. W.: Health effects of fine particulate air pollution: Lines that connect, J. Air Waste Ma., 56(6), 709742, 2006.

Randerson, J. T., van der Werf, G. R., Collatz, G. J., Giglio, L., Still, C. J., Kasibhatla, P., Miller, J. B., White, J. W. C., DeFries, R. S., and Kasischke, E. S.: Fire emissions from $\mathrm{C}_{3}$ and $\mathrm{C}_{4}$ vegetation and their influence on interannual variability of atmospheric $\mathrm{CO}_{2}$ and $\mathrm{d}^{13} \mathrm{CO}_{2}$, Global Biogeochem. Cy., 19, 
GB2019, doi:10.1029/2004GB002366, 2005.

Reid, J. S., Hyer, E. J., Prins, E. M., Westphal, D. L., Zhang, J., Wang, J., Christopher, S. A., Curtis, C. A., Schmidt, C. C., Eleuterio, D. P., Richardson, K. A., and Hoffman J. P.: Global Monitoring and Forecasting of Biomass-Burning Smoke: Description of Lessons from the Fire Locating and Modeling of Burning Emissions (FLAMBE) Program, IEEE J. Sel. Top. Appl., 2(3), 144-162, 2009.

Roy, D. P. and Boschetti, L.: Southern Africa validation of MODIS, L3JRC, and GlobCarbon Burned-Area Products, IEEE Trans. Geosci. Remote Sens., 47(4), 1032-1044, 2009.

Soja, A. J., Cofer, W. R., Shugart, H. H., Sukhinin, A. I., Stackhouse, P. W., McRae, D. J., and Conard, S. G.: Estimating fire emissions and disparities in boreal Siberia (1998-2002), J. Geophys. Res., 109, D14S06, doi:10.1029/2004JD004570, 2004.

Stavrakou, T., Müller, J.-F., De Smedt, I., Van Roozendael, M., van der Werf, G. R., Giglio, L., and Guenther, A.: Evaluating the performance of pyrogenic and biogenic emission inventories against one decade of space-based formaldehyde columns, Atmos. Chem. Phys., 9, 1037-1060, doi:10.5194/acp-9-1037-2009, 2009.

Tansey, K., Beston, J., Hoscilo, A., Page, S. E., and Paredes Hernandez, C. U.: Relationship between MODIS fire hotspot count and burned area in a degraded tropical peat swamp forest in Central Kalimantan, Indonesia, J. Geophys. Res., 113, D23112, doi:10.1029/2008JD010717, 2008a.

Tansey, K., Gregoire, J.-M., Defourny, P., Leigh, R., Pekel, J.F., van Bogaert, E., and Bartholome, E.:, A new, global, multi-annual (2000-2007) burnt area product at $1 \mathrm{~km}$ resolution, Geophys. Res. Lett., 35, L01401, doi:10.1029/2007GL031567, 2008b.

van der Werf, G. R., Randerson, J. T., Collatz, G. J., Giglio, L., Kasibhatla, P. S., Avelino, A., Olsen, S. C., and Kasischke, E. S.: Continental-scale partitioning of fire emissions during the 19972001 El Nino/La Nina period, Science, 303, 73-76, 2004.

van der Werf, G. R., Randerson, J. T., Giglio, L., Collatz, G. J., Kasibhatla, P. S., and Arellano Jr., A. F.: Interannual variability in global biomass burning emissions from 1997 to 2004, Atmos. Chem. Phys., 6, 3423-3441, doi:10.5194/acp-6-3423-2006, 2006.

van der Werf, G. R., Randerson, J. T., Giglio, L., Collatz, G. J., Mu, M., Kasibhatla, P. S., Morton, D. C., DeFries, R. S., Jin, Y., and van Leeuwen, T. T.: Global fire emissions and the contribution of deforestation, savanna, forest, agricultural, and peat fires (19972009), Atmos. Chem. Phys., 10, 11707-11735, doi:10.5194/acp10-11707-2010, 2010.
WRAP (Western Regional Air Partnership): 2002 Fire Emission Inventory for the WRAP Region- Phase II, Project No. 178-6, available at: http://www.wrapair.org/forums/fejf/ tasks/FEJFtask7PhaseII.html (last access: 10 October 2010), 22 July 2005.

Wiedinmyer, C. and Neff, J.: $\mathrm{CO}_{2}$ emissions from fires in the U.S., Implications for policy, Carbon Balance and Management, 2, 10, 1 November 2007.

Wiedinmyer, C., Quayle, B., Geron, C., Belote, A., McKenzie, D., Zhang, X., O’Neill, S., and Wynne, K. K.: Estimating emissions from fires in North America for Air Quality Modeling, Atmos. Environ., 40, 3419-3432, 2006.

Yevich, R. and Logan, J. A.: An assessment of biofuel use and burning of agricultural waste in the developing world, Global Biogeochem. Cy., 17, 1095, doi:10.1029/2002GB001952, 2003.

Yokelson, R. J., Griffith, D. W. T., and Ward D. E.: Openpath Fourier transform infrared studies of large-scale laboratory biomass fires, J. Geophys. Res.-Atmos., 101(D15), 2106721080, 1996.

Yokelson, R. J., Christian, T. J., Karl, T. G., and Guenther, A.: The tropical forest and fire emissions experiment: laboratory fire measurements and synthesis of campaign data, Atmos. Chem. Phys., 8, 3509-3527, doi:10.5194/acp-8-3509-2008, 2008.

Yokelson, R. J., Crounse, J. D., DeCarlo, P. F., Karl, T., Urbanski, S., Atlas, E., Campos, T., Shinozuka, Y., Kapustin, V., Clarke, A. D., Weinheimer, A., Knapp, D. J., Montzka, D. D., Holloway, J., Weibring, P., Flocke, F., Zheng, W., Toohey, D., Wennberg, P. O., Wiedinmyer, C., Mauldin, L., Fried, A., Richter, D., Walega, J., Jimenez, J. L., Adachi, K., Buseck, P. R., Hall, S. R., and Shetter, R.: Emissions from biomass burning in the Yucatan, Atmos. Chem. Phys., 9, 5785-5812, doi:10.5194/acp-9-5785-2009, 2009.

Yokelson, R. J., Burling, I. R., Urbanski, S. P., Atlas, E. L., Adachi, K., Buseck, P. R., Wiedinmyer, C., Akagi, S. K., Toohey, D. W., and Wold, C. E.: Trace gas and particle emissions from open biomass burning in Mexico, Atmos. Chem. Phys., 11, 67876808, doi:10.5194/acp-11-6787-2011, 2011. 